Elsevier Editorial system(tm) for Lithos Manuscript Draft

Manuscript Number: LITHOS6733R2

Title: The Mesozoic and Palaeozoic granitoids of north-western New Guinea

Article Type: Regular Article

Keywords: Granite; Bird's Head; Gondwana; Geochronology; Zircon; Geochemistry

Corresponding Author: Mr. Benjamin Michael Jost, MSc.

Corresponding Author's Institution: Southeast Asia Research Group, Royal Holloway University of London, Egham, Surrey, UK, TW20 OEX

First Author: Benjamin Michael Jost, MSc.

Order of Authors: Benjamin Michael Jost, MSc.; Max Webb; Lloyd T White

Abstract: A large portion of the Bird's Head Peninsula of NW New Guinea is an inlier that reveals the pre-Cenozoic geological history of the northern margin of eastern Gondwana. The peninsula is dominated by a regional basement high exposing Gondwanan ('Australian') Palaeozoic metasediments intruded by Palaeozoic and Mesozoic granitoids. Here, we present the first comprehensive study of these granitoids, including field and petrographic descriptions, bulk rock geochemistry, and $\mathrm{U}-\mathrm{Pb}$ zircon age data. We further revise and update previous subdivisions of granitoids in the area. Most granitoids were emplaced as small to mediumscale intrusions during two episodes in the Devonian-Carboniferous and the Late Permian-Triassic, separated by a period of apparent magmatic quiescence. The oldest rocks went unrecognised until this study, likely due to the younger intrusive events resetting the $\mathrm{K} \neg$-Ar isotopic system used in previous studies. Most of the Palaeozoic and Mesozoic granitoids are peraluminous and in large parts derived from partial melts of the country rock. This is corroborated by local migmatites and country rock xenoliths. Although rare, the metaluminous and mafic rocks show that partial melts of mantle-derived material played a minor role in granitoid petrogenesis, especially during the Permian-Triassic. The DevonianCarboniferous granitoids and associated volcanics are locally restricted, whereas the Permian-Triassic intrusions are found across NW New Guinea and further afield. The latter were likely part of an extensive active continental margin above a subduction system spanning the length of what is now New Guinea and likely extending southward through eastern Australia and Antarctica. 


\section{ABSTRACT}

2 A large portion of the Bird's Head Peninsula of NW New Guinea is an inlier that reveals the pre-Cenozoic geological history of the northern margin of eastern Gondwana. The peninsula is dominated by a regional basement high exposing Gondwanan ('Australian') Palaeozoic metasediments intruded by Palaeozoic and Mesozoic granitoids. Here, we present the first comprehensive study of these granitoids, including field and petrographic descriptions, bulk rock geochemistry, and U-Pb zircon age data. We further revise and update previous subdivisions of granitoids in the area. Most granitoids were emplaced as small to medium-scale intrusions during two episodes in the Devonian-Carboniferous and the Late PermianTriassic, separated by a period of apparent magmatic quiescence. The oldest rocks went unrecognised until this study, likely due to the younger intrusive events resetting the $\mathrm{K}$-Ar isotopic system used in previous studies. Most of the Palaeozoic and Mesozoic granitoids are peraluminous and in large parts derived from partial melts of the country rock. This is corroborated by local migmatites and country rock xenoliths. Although rare, the metaluminous and mafic rocks show that partial melts of mantle-derived material played a minor role in granitoid petrogenesis, especially during the Permian-Triassic. The Devonian-Carboniferous granitoids and associated volcanics are locally restricted, whereas the PermianTriassic intrusions are found across NW New Guinea and further afield. The latter were likely part of an extensive active continental margin above a subduction system spanning the length of what is now New Guinea and likely extending southward through eastern Australia and Antarctica. 


\section{Research highlights:}

- We present the first comprehensive study of granitoids from NW New Guinea.

- Magmatism occurred in the Devonian-Carboniferous and the Permian-Triassic.

- Partial melting of the continental crust produced mainly peraluminous granitoids.

- The granitoids formed in an active continental margin setting.

- The Triassic rocks are part of an extensive igneous belt along eastern Gondwana. 


\title{
The Mesozoic and Palaeozoic granitoids of north-western New Guinea
}

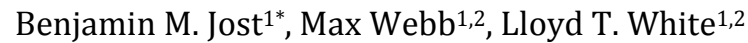

1. Southeast Asia Research Group, Royal Holloway University of London, Egham, Surrey, UK, TW20 $0 \mathrm{EX}$

2. GeoQuEST Research Centre, School of Earth and Environmental Sciences, University of Wollongong, Wollongong, NSW, Australia, 2522

*Corresponding author: Benjamin Jost (benjamin.m.jost@gmail.com)

\section{ABSTRACT}

A large portion of the Bird's Head Peninsula of NW New Guinea is an inlier that reveals the pre-Cenozoic geological history of the northern margin of eastern Gondwana. The peninsula is dominated by a regional basement high exposing Gondwanan ('Australian') Palaeozoic metasediments intruded by Palaeozoic and Mesozoic granitoids. Here, we present the first comprehensive study of these granitoids, including field and petrographic descriptions, bulk rock geochemistry, and U-Pb zircon age data. We further revise and update previous subdivisions of granitoids in the area. Most granitoids were emplaced as small to medium-scale intrusions during two episodes in the Devonian-Carboniferous and the Late PermianTriassic, separated by a period of apparent magmatic quiescence. The oldest rocks went unrecognised until this study, likely due to the younger intrusive events resetting the $\mathrm{K}$-Ar isotopic system used in previous studies. Most of the Palaeozoic and Mesozoic granitoids are peraluminous and in large parts derived from partial melts of the country rock. This is corroborated by local migmatites and country rock xenoliths. Although rare, the metaluminous and mafic rocks show that partial melts of mantle-derived material played a minor role in granitoid petrogenesis, especially during the Permian-Triassic. The Devonian-Carboniferous granitoids and associated volcanics are locally restricted, whereas the PermianTriassic intrusions are found across NW New Guinea and further afield. The latter were likely part of an extensive active continental margin above a subduction system spanning the length of what is now New Guinea and likely extending southward through eastern Australia and Antarctica. 
Keywords: Granite; Bird's Head; Gondwana; Geochronology; Zircon; Geochemistry

\section{INTRODUCTION}

North-western New Guinea represents part of the northern boundary of the Australian Plate and has experienced much Eocene to Recent tectonic activity (Fig. 1A; e.g., Baldwin et al., 2012; Davies, 2012; Hall, 2012; Pigram and Davies, 1987). While many young tectonic features are reported from the region, such as Miocene-Pliocene high-pressure metamorphic rocks (Bailly et al., 2009; François et al., 2016) and the world's youngest ultrahigh-temperature granulites (16 Ma, Pownall et al., 2014), not much is known about the earlier, pre-Cenozoic history of the area.

Some of the oldest rocks in eastern Indonesia are exposed in NW New Guinea (commonly referred to as the Bird's Head Peninsula). These Palaeozoic and Mesozoic rocks are exposed in an extensive basement high and consist of a succession of metasedimentary basement rocks punctured by granitoid intrusions (Fig. 1B; e.g., Dow et al., 1988; Pieters et al., 1983; Visser and Hermes, 1962). These rocks are considered to represent the continuation of rocks found further south in Australia along what was then part of the northern margin of eastern Gondwana (e.g., Australasian Petroleum Company, 1961; Bladon, 1988; Charlton, 2001; Crowhurst et al., 2004; Hill and Hall, 2003; Pieters et al., 1983). Yet, we still know relatively little about the Palaeozoic-Mesozoic rocks in NW New Guinea, as geological fieldwork is complicated by remoteness, difficult access, and poor exposure. Most of what is known about the area stems from field campaigns led by the Dutch Petroleum Association summarised by Visser and Hermes (1962) and a joint Indonesian-Australian mapping project in the 1970s and 1980s (cf. compilations of Dow et al., 1988; Pieters et al., 1983).

To address this relative lack of information, we present the first comprehensive field and petrographic descriptions, bulk-rock geochemistry, and U-Pb zircon geochronology of the Palaeozoic-Mesozoic granitoids of NW New Guinea. Recent road construction and development have increased accessibility and exposure, allowing more detailed and coherent fieldwork in parts of the region. Apart from the results of a recent study of the Netoni Intrusive Complex (Fig. 1, Webb and White, 2016), the only other isotopic age control on the timing of magmatism in this region are K-Ar ages from 19 samples (Bladon, 1988; Dow et al., 1988). None of these K-Ar ages have been formally published, some lack associated uncertainties or 
sampling locations, and 14 were determined on alluvial boulders collected from river detritus (a common last resort in remote rainforest locations where few exposures exist). Today, a broader range of more suitable geochronological techniques are available to measure the crystallisation age of igneous rocks. In summary, the aims of this study were to: (1) present the first encompassing petrographic and bulk-rock geochemical data of the granitoids of NW New Guinea, (2) test and, if necessary, update previous geochronological data with another isotopic system (U-Pb within zircon), and (3) suggest a tectonic setting for the formation of the granitoids. We begin with an overview of the stratigraphic framework of the Bird's Head Peninsula to provide context to interpretations of tectonic models proposed for granitoid petrogenesis.

\section{GEOLOGICAL BACKGROUND AND PREVIOUS WORK}

The two most noticeable geomorphological features of the Bird's Head are two left-lateral strike-slip fault zones, the Sorong and the Ransiki fault systems, which cross-cut the northern and north-eastern parts of the peninsula, respectively (Fig. 1). These fault zones were likely active during the past $\sim 25 \mathrm{Ma}$ (Ali and Hall, 1995; Hall, 2012) and juxtapose Eocene-Miocene volcanic arc fragments to the north and north-west with older sections of Gondwanan ('Australian') material to the south and south-west (e.g., Pieters et al., 1983). This Gondwanan continental crust is exposed in a large basement high, the Kemum Basement High (Fig. 1), which today forms part of the prominent mountain range of the peninsula. To the south and south-west, the basement is unconformably overlain by Palaeozoic and Mesozoic siliciclastic, MesozoicMiocene calcareous, and Miocene-Recent siliciclastic sediments.

Most of the granitoids that form the focus of this paper intruded country rocks exposed in the Kemum Basement High (Fig. 1B). These country rocks dominantly consist of a succession of Silurian-Devonian metaturbidites named the Kemum Formation and represent the oldest rocks in the Bird's Head Peninsula (Visser and Hermes, 1962). Field relations indicate that the Kemum Formation was regionally metamorphosed to the lower greenschist facies before the Carboniferous (Pieters et al., 1983; Visser and Hermes, 1962). Along the eastern margin of this uplifted basement block, the rocks were later overprinted by a high-temperature/low-pressure (HT/LP) phase of metamorphism, which is speculated to be associated with the intrusion of various Permian-Triassic granitoid bodies into the eastern Kemum Basement High (Figs. 1B, 2; Dow et al., 1988; Pieters et al., 1983; 1990; Robinson et al., 1990c). The 
intrusive bodies along this eastern margin have previously been grouped into three granitoid units: the Permian Warjori Granite, the Triassic Wariki Granodiorite, and the Triassic Anggi Granite. Table 1 summarises previous knowledge of all granitoid units relevant to this study; a concise and comprehensive description of all the units based on previous work is provided in Supplementary Data File 1. At its western termination, the Kemum Formation is cross-cut by the Melaiurna Rhyolite (new name; originally termed the Melaiurna Granite by Visser and Hermes (1962)). The Kemum Formation and Melaiurna Rhyolite are unconformably overlain by siliciclastic sediments of the Late Carboniferous-Permian Aifam Group, the oldest sedimentary unit from the Bird's Head (Amri et al., 1990; Pigram and Sukanta, 1989).

During the Permian-Triassic, the Bird's Head Peninsula was largely exposed above sea level, likely due to uplift associated with the development of a continental arc (Gold et al., 2017, Gunawan et al., 2012; 2014; Webb and White 2016). One product of this arc is the Netoni Intrusive Complex, a granitoid complex entirely fault-bounded by the Sorong Fault System to the north of the Kemum Basement High (Fig. 1). The complex was recently described by Webb and White (2016) and consists of granite, granodiorite, quartz monzonite, and quartz syenite with subordinate diorite, quartz diorite, and pegmatite dykes (Pieters et al., 1989; Webb and White, 2016). The granitoids are calc-alkaline and peraluminous in composition, containing xenoliths of gabbro, diorite, amphibolite, and hornblende schist (Pieters et al., 1989; Webb and White, 2016). We do not investigate this unit further in this paper, but simply refer to the existing data to draw comparisons with the other granitoids found across the peninsula. The Triassic Sorong Granite is found west of the Netoni Intrusive Complex and is also bounded by the Sorong Fault System (Fig. 1B, Tab. 1; Amri et al., 1990). Arc magmatism seems to have terminated by the Late Triassic to Early Jurassic and terrestrial to shallow marine deposition resumed (i.e., Late Triassic-Jurassic Tipuma Formation, Fig. 2; Gold et al., 2017; Gunawan et al., 2012; 2014, Pieters et al., 1983; Visser and Hermes, 1962).

The Bird's Head Peninsula is connected to mainland New Guinea via the arcuate 'Bird's Neck' isthmus (Fig. 1). The post-Mesozoic geology of the Bird's Neck is reportedly different to that of the Bird's Head (Fig. 1B; Pieters et al., 1983; 1990). This isthmus predominantly consists of multiply folded Mesozoic-Cenozoic calcareous and siliciclastic sediments known as the Lengguru Fold Belt (Fig. 1B; e.g., Bailly et al., 2009). The deformation associated with the formation of this belt also led to the uplift of several N-S trending ridges that expose basement material. These are found east of the Lengguru Fold Belt within Cendrawasih 
Bay and include the Wandaman Peninsula (Miocene-Pliocene high-grade metamorphic rocks) and the Kwatisore-Maransabadi Ridge (Permian-Triassic granitoids and older metasediments) (Bailly et al., 2009; Bladon, 1988; François et al., 2016; Pieters et al., 1983) (Fig. 1B). The latter comprises two more Permian-Triassic granitoid units, the Kwatisore Granite and the Maransabadi Granite (Fig. 1B, Tab. 1; Bladon, 1988; Pieters et al., 1983; Robinson et al., 1990b).

\section{METHODOLOGY}

\subsection{Field work and sample collection}

This study is based on field observations and samples collected across the study area during $\sim 15$ weeks of fieldwork between 2013 and 2015 as well as several samples of the Maransabadi and Kwatisore granites that were provided by John Decker from a 2012 field campaign. The locations of the sample sites and other metadata are summarised in Supplementary Data File 2. Of the 56 samples examined in this study, 13 were collected from the alluvium of rivers and 5 were collected from the scree below highly weathered outcrops. The alluvium was only sampled where weathering, vegetation, or difficult access did not permit the collection of fresh in-situ material. We present petrographic descriptions from 46 thin sections (cf. Supplementary Data File 3 for qualitative modal compositions); 40 bulk-rock geochemical analyses; and LA-ICP-MS U-Pb isotopic measurements of zircon from 35 samples (9 alluvial samples and 2 scree samples), 32 of which yielded a quantitative estimate for the crystallisation age of the respective granitoid. Please note that we follow the procedure of previous authors in grouping igneous rocks of similar petrographic, geochemical, and geochronological characteristics into lithostratigraphic units, even if samples were collected from seemingly unrelated intrusions.

\subsection{Geochemistry}

Bulk rock geochemical analyses of major and trace element compositions were acquired using a 2010 PANalytical sequential X-ray fluorescence spectrometer at Royal Holloway University of London (RHUL). Measurement procedures follow Thirlwall et al. (2000). Samples were crushed into 2-5 $\mathrm{cm}^{3} \mathrm{fragments}_{\text {, }}$ wet sieved with a coarse mesh size $(3.5 \mathrm{~mm}$ or $5.6 \mathrm{~mm})$ to avoid cross-contamination, and dried. Fragments showing minimal alteration were then ground to a fine-grained powder using a tungsten carbide rotary mill. Major element analyses were performed on fusion disks after ignition of the sample powder at $1100^{\circ} \mathrm{C}$ for $\sim 2 \mathrm{~h}$; $\mathrm{LiBO}_{3}$ was used as flux. Trace elements were analysed on $40 \mathrm{~mm}$ pressed 
pellets, using a PVP-MC (Polyvinylpyrrolidone-Methyl Cellulose) gluing agent. For this, matrix corrections were calculated from the major element compositions and calibrated against up to 40 international standards. Limits of detection for the major and trace elements were determined using long-term reproducibility data. The software GCDkit 3.00 (Janoušek, 2006) was used for various calculations and plotting. Iron was measured as total $\mathrm{Fe}_{2} \mathrm{O}_{3}$, but recalculated and plotted as total $\mathrm{FeO}\left(\mathrm{FeO}_{\mathrm{t}}\right)$.

\subsection{U-Pb zircon dating}

The geochronological data presented here were determined by $\mathrm{U}-\mathrm{Pb}$ dating of zircon grains using laser ablation inductively coupled plasma mass spectrometry (LA-ICP-MS) at the London Geochronology Centre, University College London (UCL). Cathodoluminescence (CL) images of polished grain mounts were recorded using a Hitachi S3000 scanning electron microscope at RHUL or a Jeol8100 electron probe micro analyser at UCL to assess zircon textures (Supplementary Data File 4). The UCL ESI NWR $193 \mathrm{~nm}$ laser ablation system coupled to an Agilent 7700 quadrupole ICP-MS was used to analyse 40-50 zircon grains per sample (if the sample allowed). This work used the measurement parameters of Jackson et al. (2004). See Supplementary Data File 5 for further specifications.

Plešovice zircon (337.13 \pm 0.37 Ma; Sláma et al., 2008) was measured as an external age standard. The LAICP-MS data were reduced with Iolite 2.5 (Paton et al., 2010; 2011) supplemented by the VizualAge data reduction scheme (Petrus and Kamber, 2012). In addition, TEMORA 2 (416.78 \pm 0.33 Ma; Black et al., 2004) was measured as a secondary standard and treated as an unknown during data reduction. This allowed the calculation of an excess variance for each measurement session, which was subsequently propagated onto the internal uncertainties of each individual measurement of the respective session. Measurements with discordance $\leq 10 \%$ (within 1s) were treated as concordant and only the ${ }^{206} \mathrm{~Pb} /{ }^{238} \mathrm{U}$ age of concordant analyses was used for further calculations (except inherited cores with a ${ }^{206} \mathrm{~Pb} /{ }^{238} \mathrm{U}$ age $>1000 \mathrm{Ma}$, for which the ${ }^{207} \mathrm{~Pb} /{ }^{206} \mathrm{~Pb}$ age is reported instead). Age interpretation and uncertainty propagation follow the community standard outlined by Horstwood et al. (2016) and age populations are assumed to be normally distributed (MSWD $\sim 1, \mathrm{p}=0.05$ ). Supplementary Data File 6 describes measurement procedures and the data treatment in more detail.

\section{RESULTS}


Our division of the igneous rocks of NW New Guinea into different lithostratigraphic units builds on associations made in previous studies (e.g., Dow, 1988; Pieters et al., 1983; 1990, Visser and Hermes, 1962) but also accommodates the necessary changes required by new petrographic, geochemical, and geochronological data. Our new subdivision therefore differs from that of previous studies in some respects (and therefore differs from that shown in Table 1). This section describes our findings according to the new subdivision, the reasoning behind which is discussed in Section 5.1. See Supplementary Data File 7 for representative images of all units.

\subsection{Field observations and petrography}

\subsubsection{Devonian-Carboniferous}

The Mariam Granodiorite (new name) was sampled from two intrusions in the NE and the SE Kemum Basement High (Fig. 2). Our observations of these intrusives are restricted to intensely weathered outcrops and undercuts along gravel roads. The unit consists of a medium- to coarse-grained granodiorite, with plagioclase predominating over abundant quartz and subordinate K-feldspar. Biotite is characteristic and the only peraluminous phase present; it is often retrogressed to chlorite (Supp. Data File 7). Opaques, apatite, zircon, and titanite are common accessory phases.

The Ngemona Granite (new name) represents stocks, dykes, and sills that intrude the higher-grade Kemum Formation (Figs. 2, 3A). The name is derived from the Ngemona River, which drains Lake Giji into the Warjori River (Fig. 2). It is a medium- to coarse-grained leucogranite, consisting of quartz, plagioclase, K-feldspar (mostly microcline), primary muscovite, and often garnet and tourmaline, but lacks biotite (Fig. 4A). The rocks are highly evolved and grade into medium to coarse-grained pegmatites. The pegmatites can contain varying amounts of primary muscovite, tourmaline, and rare garnet, but are often purely quartzofeldspathic. To distinguish primary from secondary muscovite the textural conditions introduced by Miller et al. (1981) were applied: Primary muscovite must (1) have a relatively coarse grain size, comparable to other phases; (2) show clear crystal terminations; (3) not enclose or not be enclosed by a mineral from which muscovite may have formed from alteration; and (4) be a constituent of an unaltered rock with clear igneous texture. Opaques, apatite, and zircon are common accessory phases; titanite is rare. Plagioclase is preferentially sericitised compared to K-feldspar and often shows core-and-mantle structures (Fig. 5A). Myrmekites are common where plagioclase has replaced K-feldspar (Fig. 5B). 
The Wasiani Granite (new name) was the only igneous unit not observed in situ and, like Pieters et al., (1990), we were restricted to a single alluvial sample (BJ92). The unit consists of leucocratic granite containing abundant quartz, plagioclase, and K-feldspar, supplemented with characteristic biotite that is partially retrogressed to chlorite (Fig. 4B). Zircon and apatite are abundant accessory minerals. Another alluvial sample of a melanocratic monzonite was found (BJ93) at the same location. This rock contains amphibole and partially retrogressed biotite next to abundant plagioclase and K-feldspar. Accessory minerals include opaques, titanite, apatite, and zircon (Fig. 4C). Along the same river transect, downstream (ENE) of where the two float samples were collected (Fig. 2), the country rock is crosscut by leucocratic pegmatite dykes ( 5-120 cm thick), which were sampled in situ (BJ98, BJ104A; Fig. 4D). These pegmatites contain abundant muscovite and rare kyanite and tourmaline. One pegmatite dyke generated a narrow zone of contact metamorphism (hornfels) in the country rock that was subsequently folded and boudinaged (Fig. 3B).

The Kwok Granite (new name) is exposed in the easternmost part of the Kemum Basement High (Fig. 2) where it intrudes the highest-grade metamorphic basement rocks as dykes or small stocks, which are metres to tens of metres thick. The leucocratic granitoid contains fractured garnet, partially resorbed but likely primary muscovite, and abundant sillimanite (fibrolite) next to partially resorbed biotite, abundant retrogressed plagioclase, orthoclase, and quartz (Fig. 4E, 5C). Opaques, apatite, and zircon are common accessory phases. Fibrolite grows on biotite sheets (Fig. 5C) and seems to replace feldspars (Fig. 4E). The rock also displays a weak gneissose texture and is locally associated with coarse-grained pegmatites. In close proximity to the Kwok Granite (locality BH15-088), metapelitic metatexites are exposed, showing pockets and layers of leucosome within volumetrically dominant cordierite-bearing melanosome (Fig. 6AB).

The Melaiurna Rhyolite (name modified to reflect the petrography) is exposed at the very western termination of the basement outcrop (Fig. 1B). While Visser and Hermes (1962) originally described this as a granite, we classify it as a volcanic rock due to its subvolcanic, porphyritic texture: phenocrysts of rounded and embayed quartz, muscovite, plagioclase, and orthoclase up to $15 \mathrm{~cm}$ in length are surrounded by a red, microcrystalline groundmass composed of quartz and feldspar (Fig. 4F). The 
feldspars are almost completely replaced by sericite or clay minerals. Muscovite is marginally resorbed. In parts, veins of translucent white calcite cut the rocks (BH15-027). We did not observe any contacts with other units but walked across the covered contact to the overlying Aifam Group. This contact is likely a nonconformity, as the Aifam Group unit starts with a coarse-grained red arkose at its base that contains material derived from the Melaiurna Rhyolite. The unit then fines upwards via fine-grained sandstones into grey siltstone and black claystone. The basal arkose largely consists of components derived from the nearby rhyolite; the age of the Melaiurna Rhyolite thus provides a maximum depositional age for the Aifam Group.

Sample BJ10, collected at locality BH14-024 from the alluvium is petrographically different from all other Devonian-Carboniferous rocks. It is a mesocratic diorite, consisting mainly of plagioclase and biotite (Supp. Data File 7). The rock contains primary muscovite, indicative of a peraluminous composition. The mineral is metastable as it is only preserved when surrounded by biotite; where in contact with plagioclase, however, it is marginally replaced by a symplectitic texture. Opaques and zircon are also present. Sample BJ80 was collected from scree next to a strongly weathered outcrop of a dyke a few metres thick; it is not apparently related to the coeval Kwok Granite, as it was sampled in a different area (locality BH15-111). The sample is fresh and reveals a medium-grained leucogranite consisting of quartz, plagioclase, and muscovite with accessory garnet and tourmaline. A few grains of biotite are present but appear to be metastable. Similar to BJ10, muscovite is a primary mineral and replaced by symplectites where in contact with plagioclase (Fig. 5D).

Most of the granitoids are massive and lack magmatic foliations except at one location, where it is also cross-cut by a later shear zone (locality BH15-047). Other evidence for post-crystallisation deformation includes folded and boudinaged granite and pegmatite dykes as well as normal-separation faults displacing dykes and country rock xenoliths (Fig. 3A-B).

The granitoids also display evidence for solid-state deformation in thin section. Quartz and some of the feldspars have been subject to dynamic recrystallization. Larger, deformed grains of quartz (sometimes with chessboard subgrains and deformation lamellae) are replaced by smaller, undeformed grains (Fig. 5E). Recrystallization seems to proceed mainly by grain boundary migration (GBM) recrystallization (Fig. 
5A-B); bulging (BLG) and subgrain rotation (SGR) recrystallization are subordinate and rare, respectively. BLG recrystallization often occurs between quartz and the feldspars (Fig. 5A). The feldspars display a range of deformation or recrystallization features: Deformation twins, myrmekites, and mantle-and-core structures are common features in plagioclase within the Ngemona Granite, the Kwok Granite, and the Mariam Granodiorite (Fig. 5A-B). In sample BJ83, a fine-grained, garnet- and biotite-bearing granite, quartz blebs exsolved from microcline with flame-perthite textures (Fig. 5F). Tourmaline is often euhedral, forming long, stretched and broken crystals; primary micas are often bent, kinked, or partially resorbed. Despite the common solid-state deformation, a clear and dominant foliation was only observed in sample BJ67 (Kwok Granite).

\subsubsection{Permian-Triassic}

A few intensely weathered and deformed outcrops of the Wariki Granodiorite (revised unit) were observed during a river transect into the NE Kemum Basement High (locality BH14-17). Sample BJ02 likely represents a weathered granodiorite characterised by chlorite after biotite and secondary, interstitial muscovite. It is associated with quartzofeldspathic pegmatite or leucogranite dykes (Fig. 4G) that intrude the country rocks that are different from the metapelites associated with DevonianCarboniferous granitoids. The country rocks encompass steeply dipping, black slates and layered, amphibole-bearing, and quartz-rich rocks that we tentatively interpret as low-grade metavolcanic rocks. The granodiorites are pervasively brittlely deformed and cut by several faults of various orientations. In thin section, brittle deformation (cataclasis, fracturing, kinking) is ubiquitous and predominates over ductile deformation (BLG recrystallization in quartz, deformation twins in plagioclase) (Fig. 4G). Just a few kilometres to the SW are exposures of the Mariam Granodiorite, which lack structures indicating pervasive brittle deformation.

The Anggi Intrusive Complex (revised unit) is exposed in the SE of the Kemum Basement High (Fig. 2) and encompasses a range of lithologies. Sample BJ138 is a granite containing < $1 \mathrm{~mm}$ garnets within sheets of biotite next to quartz, feldspar, zircon, and opaques (Fig. 4H). A diorite consisting of plagioclase and chlorite as the alteration product of biotite, titanite, and opaques is exposed at locality BH15-173 (sample BJ134; Fig. 4I). In two leucocratic diorites (BJ124, LW13-6D), hornblende reacting to chlorite, plus garnet coronae growing on biotite and quartz occur next to plagioclase, quartz, opaques, and zircon (Fig. 4J). 
Country rock xenoliths and roof pendants are abundant (Fig. 3C-D), and garnet crystals preferentially occur in the vicinity of these. At locality BH15-174, a granite intrudes metacalcareous metasediments but contains xenoliths of a metapsammitic to metapelitic rock. Despite the apparent contrast in lithology, some of the xenoliths show bedding that dips sub-parallel to that of the country rock. Thus, it cannot be said with certainty whether the xenoliths were entrained within the magma from lower structural levels or stoped from the roof or the wall of the intrusion. The xenoliths have been stretched into pinch-andswell structures, which were later crosscut by normal-separation faults (Fig. 3D). The unit is further associated with schlieric, metapelitic diatexites (Fig. 6C-D). Compared to the migmatites associated with the Kwok Granite, the proportion of leucosome is clearly higher and the volumetrically subordinate melanosome lacks restitic anhydrous mineral phases (such as cordierite, garnet, or orthopyroxene).

The Momi Gabbro (new name) was observed along a road section through the eastern margin of the Anggi Intrusive Complex (Fig. 2). Intrusive and structural relationships between the two units were observed at locality BH15-171, where the Momi Gabbro intermingles with and cross-cuts the Anggi Intrusive Complex (Fig. 3C). The Momi Gabbro consists of gabbro and finer-grained dolerite characterised by biotite, amphibole, and augite phenocrysts (sub-)ophitically enclosing plagioclase laths. In places, the augite crystals are overgrown by rims of amphibole (uralite) (Fig. 4K). Opaques, apatite, and zircon are common accessory phases.

Fresh exposures of the Sorong Granite were observed in quarries in hummocky terrain on the northern and eastern outskirts of Sorong City (Fig. 1B). The unit consists of a heterogeneous and porphyritic pink granite with phenocrysts of pink K-feldspar in a medium to coarse-grained groundmass containing quartz, K-feldspar, biotite, and opaques and zircon as accessory phases. Xenoliths are abundant and comprise phyllite, schist, diorite, and mafic to felsic volcanic rocks. Previously reported aplite dykes (Amri et al., 1990) were not observed, whereas medium-grained pegmatite dykes were. The pegmatite contains both deep red and white K-feldspar crystals as well as coarse quartz crystals with possible garnet inclusions (Supp. Data File 7). The dykes show a sharp contact with the lighter pink main granite body. Many outcrops display intense cataclastic deformation producing large aggregates of brecciated quartz or feldspar surrounded by fine-grained granite; this deformation is likely associated with movement along the Sorong Fault System. 
The Maransabadi Granite is exposed on the eponymous small island to the east of the Bird's Head Peninsula (Fig. 1B). The unit consists of medium-grained granite and granodiorite composed of quartz, partially sericitised plagioclase and K-feldspar, chlorite as the alteration product of biotite, and opaques, apatite, zircon, and titanite as accessory phases (Supp. Data File 7).

The Kwatisore Granite is exposed over a large area in the south-eastern Bird's Neck (Fig. 1B). Our samples stem from the Kwatisore Peninsula at the margin of what might be a large pluton judging from the geological map (Robinson et al., 1990e). As only the margin of this pluton was observed, the samples are not considered representative of the whole unit. They comprise a granite and a granodiorite, both medium-grained, with biotite (retrogressed to chlorite) (Fig. 4L). The rocks contain accessory titanite, zircon, apatite, and opaque phases; the granodiorite also features amphibole and secondary calcite.

\subsection{Geochemistry}

\subsubsection{Devonian-Carboniferous}

In terms of major elements, the granites and pegmatites from the Ngemona and Wasiani granites are characterised by very high and restricted $\mathrm{SiO}_{2}$ contents (74-76 wt.\%), only little $\mathrm{FeO}_{\mathrm{t}}, \mathrm{MgO} \mathrm{CaO}$, and $\mathrm{TiO}_{2}$, and variable $\mathrm{Na}_{2} \mathrm{O}$ and $\mathrm{K}_{2} \mathrm{O}$ (Fig. 7, Supplementary Data File 8). The Mariam Granodiorite (65-70 wt.\% $\mathrm{SiO}_{2}$ ) exhibits the same trends, but less pronounced. The major element composition of the Kwok Granite (BJ67) and sample BJ80 is similar to that of the Ngemona and Wasiani granites, except that they are slightly less acidic (72-73 wt.\% $\mathrm{SiO}_{2}$, Fig. 7). The Melaiurna Rhyolite ranges from 73 to 77 wt. $\% \mathrm{SiO}_{2}$, and is enriched in $\mathrm{FeO}_{\mathrm{t}}, \mathrm{MgO}, \mathrm{K}_{2} \mathrm{O}$, and $\mathrm{TiO}_{2}$ relative to other samples of similar silica content. All rocks of these units have a comparable and relatively high $\mathrm{Al}_{2} \mathrm{O}_{3}$ content of $12-17$ wt.\%. Diorite BJ10 and monzonite BJ93 are distinctly more basic (55 and 51 wt.\% $\mathrm{SiO}_{2}$, respectively), richer in $\mathrm{FeO}_{\mathrm{t}}, \mathrm{MgO}, \mathrm{CaO}$, $\mathrm{TiO}_{2}$, and especially $\mathrm{Al}_{2} \mathrm{O}_{3}$ (23 and 19 wt.\%, respectively). Based on their aluminium saturation index $\left(\mathrm{ASI}^{2} \mathrm{Al}_{2} \mathrm{O}_{3} /\right.$ $\left[\mathrm{CaO}+\mathrm{Na}_{2} \mathrm{O}+\mathrm{K}_{2} \mathrm{O}\right]$; Shand, 1927; Zen, 1986), all samples are peraluminous (ASI from 1.02 to 2.07) apart from monzonite BJ93, which is metaluminous (ASI = 0.87) (Fig. 8A, Supp. Data File 8). All the peraluminous samples plot in the strongly or weakly peraluminous fields of the AFM triangle by Miller (1985) (Fig. 8B). 
Most of these samples show enriched trace element compositions, increasing with decreasing compatibility relative to a primitive mantle composition (Palme and O’Neill, 2014; Fig. 9). The samples of the Melaiurna Rhyolite and the Mariam Granodiorite show a relatively smooth profile with positive anomalies of Th, $\mathrm{U}, \mathrm{K}, \mathrm{La}$, and $\mathrm{Pb}$ and negative anomalies of $\mathrm{Sr}, \mathrm{P}$, and Ti. Their trace element compositions are remarkably similar to that of the metamorphic country rocks. The trace element composition of the Ngemona Granite also shows similarities to the country rocks, but is depleted in $\mathrm{Ba}, \mathrm{La}, \mathrm{Ce}, \mathrm{Sr}, \mathrm{P}, \mathrm{Zr}$, and $\mathrm{Ti}$, and enriched in $\mathrm{Pb}$. The pegmatites associated with the Wasiani Granite (BJ98, BJ104A) differ by a negative anomaly in $\mathrm{Nd}$. The trace elements of the Wasiani Granite (BJ92) are comparable to those of the Mariam Granodiorite, and monzonite BJ93 shows a relatively smooth pattern with relative depletion in K, $\mathrm{Ta}, \mathrm{Nb}$, and Ti. The Kwok Granite and pegmatite BJ80 show trace element patterns not unlike those of the Ngemona Granite, but with pronounced depletion in Ba and La, and enrichment in Rb and U. Diorite BJ10 conforms nicely to the trace element composition of the Kemum Formation except for prominent enrichment in Ta and Nb. Sample BJ83 has a similar trace element composition to the Ngemona Granite.

\subsubsection{Permian-Triassic}

The Permian-Triassic event produced different units of variable composition, ranging from the most acidic Sorong Granite (77-80 wt.\% $\left.\mathrm{SiO}_{2}\right)$ and sample $\mathrm{BJ} 138$ of the Anggi Intrusive Complex $\left(74 \mathrm{wt}^{2} \% \mathrm{SiO}_{2}\right)$, to the most basic rocks of the Momi Gabbro (46-49 wt.\% $\mathrm{SiO}_{2}$; Fig. 7). Regarding their major element composition, samples of the Sorong Granite are indistinguishable from the coeval granites of the Netoni Intrusive Complex (Webb and White, 2016) and the older Kwok and Ngemona granites. The Maransabadi and Kwatisore granites, the Wariki Granodiorite, as well as samples BJ134 and BJ135 of the Anggi Intrusive Complex are compositionally similar to the Mariam Granodiorite, but exhibit a larger spread in $\mathrm{SiO}_{2}$ composition (60-70 wt.\%). Sample BJ01 is a quartzofeldspathic pegmatite associated with the Wariki Granodiorite and contains more silica (78 wt.\%). The Wariki Granodiorite (BJ02) is slightly depleted in $\mathrm{TiO}_{2}$ and enriched in $\mathrm{FeO}_{\mathrm{t}}$ and $\mathrm{P}_{2} \mathrm{O}_{5}$ relative to the other samples of similar silica content and age; sample BJ135 is richer in $\mathrm{CaO}$ and $\mathrm{TiO}_{2}$, but lower in $\mathrm{Na}_{2} \mathrm{O}$ and $\mathrm{K}_{2} \mathrm{O}$. These trends are almost reversed in diorite BJ134 associated with the Anggi Intrusive Complex: relative to other samples of similar silica content (62 wt.\%) it contains less $\mathrm{FeO}_{\mathrm{t}}, \mathrm{K}_{2} \mathrm{O}$, and $\mathrm{TiO}_{2}$, but is strongly enriched in $\mathrm{Na}_{2} \mathrm{O}$. The more basic, garnetiferous diorites $\mathrm{BJ} 124$ and LW13-6D (55-56 wt.\% $\mathrm{SiO}_{2}$ ) are compositionally similar to sample $\mathrm{BJ} 10$ but are even richer in $\mathrm{Al}_{2} \mathrm{O}_{3}$ (24-26 wt.\%). The Momi Gabbro shows the highest values of $\mathrm{FeO}_{\mathrm{t}}, \mathrm{MgO}$, and CaO of all 
samples presented in this study. It is the only metaluminous unit of Permian-Triassic age (ASI $=0.66-$ 0.75); all other samples are peraluminous with ASI values from 1.01 to 1.38 (Fig. 8).

The trace element patterns of the Wariki Granodiorite (sample BJ02) and the Maransabadi and Kwatisore granites are comparable and show similarities with the Mariam Granodiorite and the metamorphic basement rocks of the Kemum Formation (Fig. 9). The granites show a slight relative depletion in Cs. The trace element patterns of the Sorong Granite are similar to those of the Ngemona Granite with relative depletion in $\mathrm{Cs}$ and $\mathrm{P}$, and enrichment in $\mathrm{Ba}, \mathrm{Th}, \mathrm{U}, \mathrm{Nb}, \mathrm{Zr}$, and Ti. Samples grouped with the Anggi Intrusive Complex show a distinct trace element pattern different from all other samples; the trends are comparable although variations are large: $\mathrm{Th}, \mathrm{La}, \mathrm{Ce}, \mathrm{Nd}, \mathrm{Hf}, \mathrm{Zr}$, and $\mathrm{Sm}$ are noticeably enriched, while $\mathrm{K}$ and Ta are slightly depleted. The Momi Gabbro shows a relatively flat trace element pattern with enrichment in $\mathrm{Pb}$ and $\mathrm{Sm}$ and depletion in $\mathrm{Th}, \mathrm{P}$, and $\mathrm{Hf}$.

\subsection{Geochronology}

Of the 35 dated samples, 32 yielded meaningful age data. These fall into two distinct episodes lasting from the Late Devonian to the Late Mississippian (363-328 Ma) and the Late Permian to the Late Triassic (257223 Ma; Figs. 10-11). No evidence for magmatism was found for the approximately 70 Myr between these two episodes. Palaeozoic magmatism seems to have peaked in the Tournaisian (355 Ma) and the Serpukhovian (330 Ma). Samples BJ92 (Wasiani Granite), MW15-022 (Sorong Granite), and BJ58 (a weathered volcanic dyke sampled in the north-eastern Kemum Basement High; BH15-080) did not yield sufficient concordant analyses to allow the calculation of a weighted mean age. The few concordant analyses we did obtain, however, indicate that the Wasiani Granite (BJ92) is part of the Palaeozoic episode, while the other two samples (MW15-022 and BJ58) intruded in the Permian-Triassic episode (Supplementary File 9). Tera-Wasserburg diagrams for all samples are given in Supplementary Data File 10 and a table summarising all weighted mean ages is given Supplementary Data File 11.

Most of the zircons analysed for this study are euhedral crystals with magmatic zonation visualised by CL imaging (Fig. 12A). A few samples, however, yielded zircons that have a different morphology and appearance in CL: for example, (1) predominantly xenomorphic grains without visible zonation (BJ93, Fig. 12B), (2) broken grains that were subsequently welded together by thin metamorphic zircon (BJ02, Fig. 
12C), and (3) eu- to anhedral grains that are noticeably CL-dark and lack apparent zonation (BJ08, Fig. 12D). For the latter group, which includes samples BJ08, BJ09, and BJ80, many analyses had to be rejected during the calculation of a mean age due to a large spread in ages (Fig. 10). For these samples, still concordant younger ages become progressively more discordant: they lie on a discordia or mixing line away from the most concordant population (Supplementary Data File 12). This likely reflects partial $\mathrm{Pb}$ loss within several zircon grains from each of these samples. CL imagery further indicates that some of the analysed zircon grains are composed of magmatic overgrowths on rounded inherited cores, some of which yielded concordant Early Palaeozoic and Proterozoic ages (Fig. 12E-H).

\section{DISCUSSION}

\subsection{Subdivisions of igneous rocks}

Several new units have been defined and some of the previous units re-named or re-defined to accommodate the data presented here: the Mariam Granodiorite and the Ngemona, Wasiani, and Kwok granites reflect the newly recognised Palaeozoic granitoids, the Momi Gabbro refers to newly found mafic rocks associated with the Anggi Intrusive Complex, and the Melaiurna Rhyolite accounts for the hypabyssal nature of the previous 'Melaiurna Granite' (Amri et al., 1990; Visser and Hermes, 1962). But please note that, like previous authors (e.g., Pieters et al., 1990), we use some of these names (i.e., Anggi Intrusive Complex, Mariam Granodiorite, Ngemona Granite, Wasiani Granite) collectively for different igneous rocks found in certain areas that could not be clearly subdivided due to limited field observations. There are also several samples or localities that were not classified to a particular intrusive unit, mainly because of insufficient data (this includes samples BJ10, BJ80, and BJ83 and the tentative allocation of monzonite BJ93 to the Wasiani Granite).

\subsection{Episodes of magmatism}

Carboniferous (329-328 Ma) and Permian-Triassic (257-223 Ma) magmatism was recognised and described by previous workers (e.g., Bladon, 1988; Tab. 1), but ages corresponding to the oldest rocks reported here $(\sim 355 \mathrm{Ma})$ have not been reported previously. This might reflect a sampling bias: As previous authors collected all but one of their samples from the alluvium (Bladon, 1988), we can never be sure that we dated exactly the same granitoid units they did. The ages previously reported for the Anggi Granite (as defined by Pieters et al. (1983; 1990)) agree with the U-Pb ages of the Anggi Intrusive 
Complex (as defined here). However, for the Wariki Granodiorite, Bladon (1988) reported five PermianTriassic ages from an area, where we also found Devonian-Carboniferous ages of the Mariam Granodiorite next to one sample of the Late Permian Wariki Granodiorite (sample BJ02). Also, U-Pb ages of the granitoids in the higher-grade Kemum Formation north of lakes Giji and Gida (cf. Fig. 2) are exclusively Palaeozoic (with the exception of sample BJ58) and apparently contradict to the Permian-Triassic ages reported in Dow et al. (1988). Such discrepancies between the ages of previous studies and those presented here cannot be explained by a sampling bias.

The potential discrepancy between ages reported here and those of previous authors (Bladon, 1988; Dow et al., 1988) for the same granitoid unit could be due to resetting the K-Ar system by (1) intense alteration or (2) a thermal event. We assume that the K-bearing minerals previously dated from alluvial samples (as summarised in Bladon, 1988) were likely less altered and led to reliable K-Ar ages, as alluvial samples are always fresh and resistant to weathering, compared to granitoid outcrops, which are often intensely weathered. The resetting of the K-Ar system by a thermal event on the other hand is more likely due to a number of reasons: (1) the extensive Permian-Triassic magmatism (Figs. 1, 2, 11); (2) a regional HT/LP metamorphic event (Pieters et al., 1990) with mineral assemblages suggesting temperatures in excess of $500^{\circ} \mathrm{C}$; (3) the fact that previous $\mathrm{K}-\mathrm{Ar}$ ages were predominantly obtained from biotite, muscovite, and plagioclase $(n=24)$, which have lower closure temperatures for Ar than hornblende $(n=6)$ (e.g., Reiners et al., 2005 and references therein); and (4) that previous authors themselves assumed that some of their samples had been thermally disturbed and thus likely reset (Bladon, 1988). We therefore propose that the thermal anomaly caused by the intrusion of the Permian-Triassic granitoids reset the K-Ar system of older granitoids in the eastern Kemum Basement High, without this affecting their zircon U-Pb age.

This is supported by microstructural observations, most of which stem from Devonian-Carboniferous granitoids, and all of which indicate recovery and recrystallization at high temperatures $\left(>400{ }^{\circ} \mathrm{C}\right)$ and low strain rates $\left(<10^{-14} \mathrm{~s}^{-1}\right)$. Low strain rates are indicated by the absence of foliations, the scarceness of elongated subgrains, as well as the predominance of grain boundary migration recrystallization over bulging and subgrain rotation recrystallization in quartz. The type of dynamic recrystallization in quartz depends on both strain rate and temperature and serves as a first-order temperature gauge (e.g., Passchier and Trouw, 2005): GBM recrystallization in quartz occurs above $400-500^{\circ} \mathrm{C}$ at low strain rates 
(Stipp et al., 2002a; 2002b). Also, chessboard subgrains in quartz only develop above $\sim 570^{\circ} \mathrm{C}$ at 1 kbar, and even higher temperatures at higher pressures (Kruhl, 1996). Bulbous myrmekites (Fig. 6F) also indicate recrystallization of the granitoids at similar metamorphic conditions (e.g., Phillips, 1980). Although recrystallization can be a response to syn- or post-intrusive deformation of a cooling granitoid body (e.g., Pennacchioni and Zucchi, 2013), a thermal overprint of older intrusive rocks in the eastern Kemum Basement High is likely as is indicated by the significant Permian-Triassic magmatism and concomitant regional HT/LP metamorphism (e.g., Pieters et al., 1990).

As previous authors (e.g., Dow et al., 1988; Pieters et al., 1983; 1990) underestimated the diversity of ages of granitoids from western New Guinea, it is possible that we have unintentionally done the same. A case in point is the apparent 'magmatic gap' during much of the Permian implied by our analyses (Fig. 13). This potentially reflects a sampling bias, particularly since a relatively small area of the Kemum Basement High was sampled. We must also consider that there has been uplift of the region since the Miocene accompanied by high erosion rates (Pieters et al, 1990), so there may be igneous bodies that have not yet been exposed at the surface or have already mostly been eroded away. Readers should also note that Permian ages were previously reported for the Warjori Granite (Bladon, 1988; Pieters et al., 1990) and for igneous rocks in the south of mainland New Guinea (Fig. 13). Detrital zircons from sedimentary rocks across the Bird's Head Peninsula have also yielded Permian ages (Decker et al., 2017; Gunawan, 2013). Future work may therefore reveal a local source of igneous zircons of Permian or other age.

\subsection{Petrogenesis}

The weakly to highly peraluminous mineralogy and chemistry of most granitoids of NW New Guinea indicate that they are primarily derived from partial melts of the metapsammitic to metapelitic country rock and can thus be considered S-type granitoids (Chappell and White, 1974; 1992; 2001). Partial melting of continental crustal material is supported by migmatites associated with the Kwok Granite and the Anggi Intrusive Complex, which indicate incipient and pervasive partial melting, respectively (Fig. 6). As migmatisation is not confined to the contact with intrusions, they are likely the result of regional HT/LP metamorphism as opposed to contact metamorphism. Also, abundant metasedimentary xenoliths in the Anggi Intrusive Complex corroborate the assimilation of and contamination with continental crustal material (Fig. 3C-D). The xenomorphic to skeletal appearance of garnets in the Anggi Intrusive Complex, 
their association with biotite (Fig. 4H, J), the abundance of biotite and quartz inclusions within them, and their seemingly preferred occurrence around country rock xenoliths further indicates that these are restitic xenocrysts resulting from mica dehydration reactions (i.e., peritectic phases) and originated from the country rock. It is likely that the xenoliths were incorporated and contributed to the melt at greater depths (as garnet and not cordierite formed as a peritectic phase). Lastly, the presence of rounded and concordant Precambrian zircon cores (Fig. 12E-H) provides additional evidence that the petrogenesis of many of the granitoids involved partial melting of (meta)sedimentary material.

While partial melts of the continental crust significantly contributed to the petrogenesis of both the Palaeozoic and the Mesozoic magmatic events, there are petrogenetic differences between the two groups. The Devonian-Carboniferous units (Ngemona and Kwok granites, the Melaiurna Rhyolite, and the pegmatites of the Wasiani Granite) contain abundant peraluminous minerals such as muscovite, garnet, sillimanite, tourmaline, and biotite. These represent the best examples of highly peraluminous granitoids of predominantly metasedimentary origin within NW New Guinea. The Mariam Granodiorite and the Wasiani Granite (BJ92) are also peraluminous, containing biotite but lacking metaluminous minerals such as amphibole. The trace element patterns of the Mariam Granodiorite and the Melaiurna Rhyolite are also strikingly similar to those of the country rock (Fig. 9). These units are therefore interpreted to have been derived from partial melts of the continental crust. Only a few of the Devonian-Carboniferous samples slightly deviate from this trend. For example, Monzonite BJ93 is metaluminous, slightly silica undersaturated, and relatively enriched in K, HFSE, Ba, Ta, and Nb, while Samples BJ10, BJ80, and the Kwok Granite (BJ67) are enriched in $\mathrm{Ta}$ and $\mathrm{Nb}$; the latter two also show Ti depletion. Such features are typically associated with mantle-derived within-plate magmas (Pearce, 1983; Thorpe et al., 1984).

The Permian-Triassic magmatic episode produced rocks with a more mixed signature: Many samples cannot be clearly classified as S-type granitoids, as they lack characteristic minerals and contain only mildly peraluminous biotite (Sorong Granite, Anggi Intrusive Complex, Maransabadi Granite). Further, the garnet in granites and diorites of the Anggi Intrusive Complex is likely a peritectic phase entrained from the surrounding country rock rather than a primary magmatic mineral indicative of the composition of the magma. While some of the rocks are acidic and characterised by a peraluminous modal and chemical composition (e.g., granites of the Anggi Intrusive Complex), the Kwatisore Granite and the diorites of the 
Anggi Intrusive Complex contain amphibole, titanite, and allanite: minerals indicative of mantle-derived igneous rocks (I-type rocks; Chappell and White, 1974; 1992; 2001). Although metaluminous I-type rocks can become peraluminous via extreme fractional crystallisation, this process is considered unlikely to apply here, as large volumes of metaluminous minerals have to fractionate from the magma and peraluminous I-type granitoids can constitute only about $0.1 \%$ of the outcrop area of a pure I-type pluton (Zen, 1986). The Momi Gabbro stands out as the only mafic unit known from the Kemum Basement High. Samples BJ137 and LW13-5B are fresh and clearly metaluminous, both in terms of petrography (containing pyroxene and hornblende) and geochemistry (high $\mathrm{FeO}_{\mathrm{t}}, \mathrm{MgO}$, $\mathrm{CaO}$; di normative). Trace elements show no influence of crustal contamination and only slight enrichment in LILE common of MORB or within-plate rocks (Fig. 9; Pearce, 1983). Field relations show the unit to be coeval with the Anggi Intrusive Complex, which is supported by the ages of both units (Fig. 3C).

While fractional crystallisation alone cannot explain the predominance of peraluminous rocks, it remains an important process during their petrogenesis. Fractional crystallisation of plagioclase and K-feldspar is suggested by the depletion of Sr and to a lesser degree Ba in highly evolved rocks (e.g., Ngemona, Kwok, Sorong granites and Anggi Intrusive Complex) (Brown et al., 1984). Anomalously low abundances of Ba might also be explained by the fractionation or breakdown of biotite: experimental studies indicate that tourmaline only forms in biotite-free leucogranites (e.g., Ngemona Granite) (Scaillet et al., 1995). Fractionation of garnet likely occurred in some of the pegmatites and leucosomes displaying slightly raised $\mathrm{Sr} / \mathrm{Y}$ values (>30; BJ01, BJ104A, BJ135). However, this did not significantly contribute to the remaining granitoids, which are characterised by relatively low $\mathrm{Sr} / \mathrm{Y}$ values $(0-20)$, similar to the geochemical signatures of other I- or S-type granitoids or continental crustal rocks (Moyen, 2009). Fractionation of hornblende cannot be assessed satisfactorily, as Dy was not measured.

The geochemical data of the granitoids need to be interpreted with caution as some of the analysed samples show evidence of chemical weathering or metasomatic alteration. For instance, the anomalously high $\mathrm{Na}_{2} \mathrm{O}$ coupled with very low $\mathrm{K}_{2} \mathrm{O}$ and $\mathrm{CaO}$ contents of sample BJ134 may be indicative of albitisation (Fig. 7). The high $\mathrm{K}_{2} \mathrm{O}$ and low $\mathrm{Na}_{2} \mathrm{O}$ contents of the Melaiurna Rhyolite may also reflect potassic alteration. Features indicative such alteration (e.g., anti-rapakivi structures) are not visible in thin section due to the breakdown of the feldspars. This breakdown may also partially explain the high ASI values of the 
Melaiurna Rhyolite and the Wariki Granodiorite (BJ02), as the alkalis are preferentially removed with respect to $\mathrm{Al}_{2} \mathrm{O}_{3}$ during alteration and weathering (de la Roche, 1979). One other consideration is that many of the Palaeozoic granitoids show evidence of post-crystallisation metamorphism, which may have led to some modification of their initial composition. However, the majority of the geochemical analyses were from pristine samples, e.g., the pegmatites of the Wasiani Granite (BJ104A, BJ98), which have elevated ASI values.

\subsection{Tectonic implications}

The granitoids exposed in the eastern Kemum Basement High likely represent the upper structural level of a magmatic system intruding at mid-crustal levels. Limited geophysical data exist for New Guinea, however, unexposed segments of the Paleozoic-Mesozoic magmatic belt are potentially imaged in gravity data processed with an upward continuation residual filter (White et al., 2014). These data show a series of zones of low gravity along the length of New Guinea beneath regions that were mapped as igneous rocks at the surface (cf., Fig. 12 from White et al., 2014). Considering the paucity of geophysical data and that numerous deformation phases have occurred since the granitoids were emplaced, our best indication for the emplacement depth comes from mineral assemblages in the metamorphic country rocks. For example, mineral assemblages characterised by andalusite and sillimanite (Pieters et al., 1983; 1990) indicate relatively low pressures ( $<4 \mathrm{kbar}$ ), corresponding to a depth of $\sim 15 \mathrm{~km}$ or less. The kyanite found in pegmatite BJ104A suggests that higher pressures may have been attained, but this does not necessarily apply, as pegmatitic kyanite can form via a variety of processes other than prograde metamorphism (e.g., Woodland, 1963). Although the pegmatites containing large proportions of hydrous phases such as muscovite and tourmaline are often associated with mid- to upper crustal levels, muscovite is thermodynamically unstable in granitic magma at pressures below 3-4 kbar (Zen, 1988). This suggests that the original melt formed at a greater depth and subsequently intruded at a shallower level. The magma also likely shifted from the stability field of muscovite, as is indicated by its sub-solidus replacement where in contact with feldspar (Fig. 5D). The presence of narrow zones of contact metamorphism around many intrusions (Fig. 3B) provides further support that hot magma was injected into shallower and cooler rocks, rather than these being derived from in-situ partial melting of and segregation from metasedimentary country rocks. 
The production of large amounts of metasedimentary partial melts and regional HT/LP (Abukuma-type) metamorphism overprinting the surrounding country rocks imply a high geothermal gradient and an anomalously hot continental crust. Such regional HT/LP conditions likely accompanied both the PermianTriassic and Devonian-Carboniferous episodes of magmatism, although the younger metamorphic phase partially overprinted the older phase. This is supported by the metapelitic migmatites associated with the Kwok Granite and the Anggi Intrusive Complex. The heat required to produce regional metamorphism and partial melting at low pressure was likely advected from the lower crust or mantle (e.g., DeYoreo et al., 1991). This potentially occurred over a relatively short-term (million-year) timescale (e.g., Viete and Lister, 2017) rather than due to long-term steady state processes and heating driven by radioactive decay (e.g., England and Thompson, 1984). This Abukuma-type metamorphism likely occurred when the region was part of an active continental arc system and heat flux to the crust was high (Fig. 13A; e.g., Gunawan et al., 2012; 2014; Metcalfe, 2013; Webb and White, 2016). This scenario is comparable to other HT/LP metamorphic terranes of the world where similar lithologies are observed, e.g., the Abukuma Plateau in Japan (e.g., Miyashiro, 1973) or the Cooma Metamorphic Complex in the Lachlan Fold Belt in SE Australia (e.g., Williams, 2001).

This tectonic model is further supported by the trace element compositional data. For instance, the Permian-Triassic granitoids show high LILE/HFSE ratios, enrichment in $\mathrm{Th}, \mathrm{Rb}, \mathrm{La}, \mathrm{Ce}$, and to a lesser degree $\mathrm{U}$ and $\mathrm{Ba}$, as well as depletion in $\mathrm{Ta}$ and $\mathrm{Nb}$ (e.g., Anggi Intrusive Complex) (Brown et al., 1984; Pearce, 1983; Thorpe et al., 1984). These rocks are dominantly calc-alkalic and magnesian in composition, characteristic of Cordilleran-type granitoids (Frost et al., 2001). The more basic Palaeozoic samples show a mixed signal with relatively enriched HFSE, $\mathrm{Ta}$, and $\mathrm{Nb}$ indicative of a mixture between a subductionrelated and a within-plate source (Brown et al., 1984; Pearce, 1983; Thorpe et al., 1984). Their Fe-rich alkali-calcic to alkalic composition is also indicative of granitoids inboard of a Cordilleran-type arc (Frost et al., 2001). We therefore interpret that the Permian-Triassic granitoids formed in an active continental margin setting above a subduction zone (Fig. 13), while the Palaeozoic granitoids are tentatively interpreted to represent post-orogenic magmatism or magmatism further inboard of an active margin.

The Palaeozoic granitoids described above are restricted to the Bird's Head Peninsula and represent the oldest known episode of magmatism in New Guinea and eastern Indonesia (Fig. 13). These intrusives 
represent a collection of sparse discrete exposures within the Bird's Head. They are not coeval with the Devonian to Carboniferous granitoids found in south-western New Guinea (Fig. 13; Richards and Willmott, 1970), but may potentially be part of a broader Devonian and Carboniferous orogenic belt and associated granitoid and volcanic rocks found through parts of eastern Australia and New Zealand (e.g., Black et al., 2010; Kositcin et al., 2015; Muir et al., 1996; Raymond and Sun, 1998, and references therein).

The younger Permian-Triassic granitoids are thought to represent part of a continental arc that can be traced from as far west as the Banggai-Sula islands, through the Bird's Head Peninsula and the Bird's Neck isthmus, and eastward into mainland New Guinea (Fig. 13B). The Permian-Triassic arc is also considered to extend through eastern Gondwana (what is now eastern Australia, Zealandia and Antarctica) (Fig. 13A; Amiruddin, 2009; Charlton, 2001; Crowhurst et al., 2004; Gunawan et al., 2012; 2014; Hill and Hall, 2003; Metcalfe, 2013; Webb and White, 2016).

The arrangement of intrusive bodies in NW New Guinea is complicated and partially obliterated by sinistral strike-slip movement along the Sorong Fault System. The Netoni Intrusive Complex is probably the best example of a largely fault-bounded granitoid body in this region, and its similarity to the Wariki Granodiorite and the Anggi Intrusive Complex suggest a displacement of at least $30 \mathrm{~km}$ along the Sorong Fault System (Fig. 1B; Pieters et al., 1989; Webb and White, 2016). Although only few fault-bounded contacts were observed in the field, the petrographic and geochemical data presented here suggest that there are more such examples. In contrast to the granitoids of the Ngemona Granite and the Mariam Granodiorite, the Wariki Granodiorite displays abundant brittle deformation and is associated with distinct black slates and metavolcanic country rocks. This indicates that these rocks might constitute an allochthonous block that has been transported to its current location by the Ransiki and Sorong fault systems from further east, closer to the Triassic intrusions of the Anggi Intrusive Complex and the Momi Gabbro. In addition, the Sorong Granite and the Netoni Intrusive Complex are similar in age, petrography, and geochemistry and might well represent parts of the same pluton that has been dismembered and displaced by the Sorong Fault System. Further, both units are geochemically similar to the Melaiurna Rhyolite, even though the ages are different. It is feasible that the three units have a similar origin and were displaced along the major strike-slip fault system. This idea is supported by geological maps of the region showing the units with faulted contacts (Amri et al., 1990; Pieters et al., 1989; 1990). 


\section{CONCLUSIONS}

663

664

665

666

667

668

669

670

671

672

673

674

675

676

677

678

679

680

681

682

683

684

685

686

687

688

689

Newly collected geochronological data show that magmatism in NW New Guinea occurred during two episodes in the Palaeozoic (Late Devonian-Late Mississippian) and the Early Mesozoic (Late PermianTriassic). We are the first to report evidence of Devonian-Carboniferous magmatism in the Bird's Head Peninsula, and these constitute the oldest known igneous rocks from New Guinea and eastern Indonesia. Earlier geochronological analyses of the NW New Guinea granitoids were solely based on the K-Ar method and we demonstrate that some of these measurements were potentially reset by subsequent tectono-thermal events - most likely the widespread phase of Permian-Triassic magmatism. The granitoids of NW New Guinea are predominantly evolved and peraluminous rocks that originate from partial melting of the metasedimentary continental crust (S-type granitoids). Mafic rocks (Momi Gabbro) and minor volumes of I-type rocks accompany the Permian-Triassic granitoids. These rocks likely result from magmatic activity in the continental margin above an extensive subduction zone system. A similar tectonic setting is tentatively suggested for the Devonian-Carboniferous granitoids.

\section{DATA AVAILIBILITY}

The data generated during this study are attached in the supplementary data files and are available from the EarthChem repository at (DOI link to be included upon acceptance of the manuscript).

\section{ACKNOWLEDGEMENTS}

Our thanks go to the consortium of companies who funded this research as part of the SE Asia Research Group (ENI, Murphy Oil, Repsol, Shell, Engie, Statoil, and Inpex); to John Decker and Niko Asia for donating several samples; to Roberto Dall'Agnol, Robert B. Miller, and three anonymous reviewers for helpful and constructive comments that resulted in a much improved manuscript; Robert Hall for support and helpful comments; Herwin Tiranda, Indra Gunawan, and David Gold for their invaluable contribution to fieldwork; Kevin D’Souza for hand sample photography; and Christina Manning, Matthew Thirlwall, Martin Rittner, and Andy Carter for their help in collecting geochemical and geochronological data.

\section{REFERENCES}


690

691

692

693

694

695

696

697

698

699

700

701

702

703

704

705

706

707

708

709

710

711

712

713

714

715

716

Ali, J.R., Hall, R., 1995. Evolution of the boundary between the Philippine Sea Plate and Australia: Palaeomagnetic evidence from eastern Indonesia. Tectonophysics 251, 251-275.

Amri, C., Harahap, B.H., Pieters, P.E., Bladon, G.M., 1990. The geology of the Sorong Sheet area, Irian Jaya (parts of quadrangles 2714, 2715, 2814, 2815) Scale 1: 250, 000. Geological Survey of Indonesia, Directorate of Mineral Resources, Geological Research and Development Centre, Bandung, 70pp.

Amiruddin, 2009. A Review on Permian to Triassic Active or Convergent Margin in Southeasternmost Gondwanaland: Possibility of Exploration Target for Tin and Hydrocarbon Deposits in the Eastern Indonesia. Jurnal Geologi Indonesia 4, 31-41.

Australasian Petroleum Company, 1961. The geological results of petroleum exploration in Western Papua. Journal of the Geological Society of Australia 8, 1-133.

Bailly, V., Pubellier, M., Ringenbach, J.-C., de Sigoyer, J., Sapin, F., 2009. Deformation zone 'jumps' in a young convergent setting; the Lengguru fold-and-thrust belt, New Guinea Island. Lithos 113, 306-317.

Baldwin, S.L., Fitzgerald, P.G., Webb, L.E., 2012. Tectonics of the New Guinea region. Annual Review of Earth and Planetary Sciences 40, 495-520.

Black, L. P., Everard, J. L., McClenaghan, M. P., Korsch, R. J., Calver, C. R., Fioretti, A. M., Brown, A.V., Foudoulis, C., 2010. Controls on Devonian-Carboniferous magmatism in Tasmania, based on inherited zircon age patterns, $\mathrm{Sr}, \mathrm{Nd}$ and $\mathrm{Pb}$ isotopes, and major and trace element geochemistry. Australian Journal of Earth Sciences, 57(7), 933-968.

Black, L.P., Kamo, S.L., Allen, C.M., Davis, D.W., Aleinikoff, J.N., Valley, J.W., Mundil, R., Campbell, I.H., Korsch, R.J., Williams, I.S., 2004. Improved $206 \mathrm{~Pb} / 238 \mathrm{U}$ microprobe geochronology by the monitoring of a traceelement-related matrix effect; SHRIMP, ID-TIMS, ELA-ICP-MS and oxygen isotope documentation for a series of zircon standards. Chemical Geology 205, 115-140. 
Bladon, G.M., 1988. Preliminary geological report. Catalogue, appraisal and significance of K-Ar isotopic ages determined for igneous and metamorphic rocks in Irian Jaya. Indonesia-Australia Geological Mapping Project 79pp.

Brown, G.C., Thorpe, R.S., Webb, P.C., 1984. The geochemical characteristics of granitoids in contrasting arcs and comments on magma sources. J. Geol. Soc. London. 141, 413-426. doi:10.1144/gsjgs.141.3.0413

Chappell, B.W., White, A.J.R., 1974. Two contrasting granite types. Pacific geology 8, 173-174.

Chappell, B.W., White, A.J.R., 1992. I-and S-type granites in the Lachlan Fold Belt. Geological Society of America Special Papers 272, 1-26.

Chappell, B.W., White, A.J.R., 2001. Two contrasting granite types: 25 years later. Australian Journal of Earth Sciences. 48, 489-500. doi:10.1046/j.1440-0952.2001.00882.x

Charlton, T.R., 2001. Permo-Triassic evolution of Gondwanan eastern Indonesia, and the final Mesozoic separation of SE Asia from Australia. Journal of Asian Earth Sciences 19, 595-617.

Crowhurst, P.V., Maas, R., Hill, K.C., Foster, D.A., Fanning, C.M., 2004. Isotopic constraints on crustal architecture and Permo-Triassic tectonics in New Guinea: possible links with eastern Australia. Australian Journal of Earth Sciences 51, 109-124.

Davies, H.L., 1990. Structure and Evolution of the Border Region of New Guinea. In: Petroleum Exploration in Papua New Guinea (Edited by Carman, G.J. \& Carman, Z.) Proceedings of the First PNG Petroleum Convention 245-270.

Davies, H.L., 2012. The geology of New Guinea-the cordilleran margin of the Australian continent. Episodes 35, 87-102. 
de La Roche, H., 1979. Muscovitisation deuterique, caractere alumineux des leucogranites et classification des granites subsolvus. Bulletin de la Société Géologique de France 7, 87-93.

Decker, J., Ferdian, F., Morton, A., Fanning, M., White, L.T., 2017. New geochronology data from eastern Indonesia - and aid to understanding sedimentary provenance in a frontier region. Indonesian Petroleum Association, Proceedings 41th annual convention \& exhibition, Jakarta, 2017.

De Yoreo, J. J., Lux, D. R., Guidotti, C. V., 1991. Thermal modelling in low-pressure/high-temperature metamorphic belts. Tectonophysics, 188(3-4), 209-238.

Dow, D.B., Robinson, G.P., Hartono, U., Ratman, N., 1988. Geology of Irian Jaya: Preliminary Geological Report. Geological Research and Development Centre - Bureau of Mineral Resources, Canberra.

Dow, D.B., Harahap, B.H., Sufni Hakim, A., 1990. Geology of the Enarotali Sheet area, Irian Jaya, Scale 1: 250, 000. Geological Survey of Indonesia, Directorate of Mineral Resources, Geological Research and Development Centre, Bandung, 57pp.

Ferdian, F., Decker, J., Morton, A., Fanning, M., 2012. Provenance of East Sulawesi and Banggai Sula Zircons-Preliminary Result. Indonesian Petroleum Association, Proceedings 36th annual convention \& exhibition, Jakarta, 2012.

François, C., de Sigoyer, J., Pubellier, M., Bailly, V., Cocherie, A., Ringenbach, J.-C., 2016. Short-lived subduction and exhumation in Western Papua (Wandamen peninsula): Co-existence of HP and HT metamorphic rocks in a young geodynamic setting. Lithos 266, 44-63.

Frost, B.R., Barnes, C.G., Collins, W.J., Arculus, R.J., Ellis, D.J., Frost, C.D., 2001. A geochemical classification for granitic rocks. J. Petrol. 42, 2033-2048. doi:10.1093/petrology/42.11.2033 
801

Gold, D.P., White, L.T., Gunawan, I., BouDagher-Fadel, M.K., 2017. Relative sea-level change in western New Guinea recorded by regional biostratigraphic data. Mar. Pet. Geol. 86, 1133-1158. doi:10.1016/j.marpetgeo.2017.07.016

Gradstein, F.M., Ogg, J.G., Hilgren, F.J., 2012. On the Geologic Time Scale. Newsletters on Stratigraphy 45, 171-188.

Gunawan, I., 2013. Mesozoic and Cenozoic Siliciclastic Sedimentary Rocks of the Bird's Head of New Guinea, Indonesia. Unpublished PhD thesis, SE Asia Research Group, Department of Earth Sciences, Royal Holloway University of London, 472pp.

Gunawan, I., Hall, R., Augustsson, C., Armstrong, R., 2014. Quartz from the Tipuma Formation, West Papua: New insights from geochronology and cathodoluminescence studies. Indonesian Petroleum Association, Proceedings 38th annual convention \& exhibition, Jakarta, 2014.

Gunawan, I., Hall, R., Sevastjanova, I., 2012. Age, character and provenance of the Tipuma Formation, West Papua: New insights from detrital zircon dating. Indonesian Petroleum Association, Proceedings 36th annual convention \& exhibition, Jakarta, 2012.

Hall, R., 2012. Late Jurassic-Cenozoic reconstructions of the Indonesian region and the Indian Ocean. Tectonophysics 570, 1-41.

Harding, R.R., 1969. Catalogue of Age Determinations on Australian Rocks, 1962-1965, Bureau of Mineral Resources, Geology and Geophysics.

Hijmans, R., 2014. Global Administrative Areas - Boundaries without limits [web resource]. http://gadm.org/. October 2014. 
805

806

807

808

809

810

811

812

813

814

815

816

817

818

819

820

Hill, K.C., Hall, R., 2003. Mesozoic-Cenozoic evolution of Australia's New Guinea margin in a west Pacific context. Geological Society of Australia Special Publication 22 and Geological Society of America Special Paper 372 265-289.

Horstwood, M.S.A., Košler, J., Gehrels, G., Jackson, S.E., McLean, N.M., Paton, C., Pearson, N.J., Sircombe, K., Sylvester, P., Vermeesch, P., 2016. Community-Derived Standards for LA-ICP-MS U-(Th-) Pb Geochronology-Uncertainty Propagation, Age Interpretation and Data Reporting. Geostandards and Geoanalytical Research 40, 311-332.

Jackson, S.E., Pearson, N.J., Griffin, W.L., Belousova, E.A., 2004. The application of laser ablation-inductively coupled plasma-mass spectrometry to in situ U-Pb zircon geochronology. Chemical Geology 211, 47-69.

Janoušek, V., Farrow, C.M., Erban, V., 2006. Interpretation of Whole-rock Geochemical Data in Igneous Geochemistry: Introducing Geochemical Data Toolkit (GCDkit). Journal of Petrology 47, 1255-1259.

Kositcin, N., Purdy, D. J., Brown, D. D., Bultitude, R. J., Carr, P. A., 2015. Summary of results - Joint GSQ-GA Geochronology Project: Thomson Orogen and Hodgkinson Province, 2012-2013. Queensland Geological Record 2015/02, 75pp.

Kruhl, J.H., 1996. Prism-and basal-plane parallel subgrain boundaries in quartz: A microstructural geothermobarometer. Journal of Metamorphic Geology 14, 581-589.

Metcalfe, I., 2013. Tectonic evolution of the Malay Peninsula. Journal of Asian Earth Sciences, 76, 195-213.

Miller, C.F., 1985. Are strongly peraluminous magmas derived from pelitic sedimentary sources? The Journal of Geology 93, 673-689.

Miller, C.F., Stoddard, E.F., Bradfish, L.J., Dollase, W.A., 1981. Composition of plutonic muscovite: genetic implications. Can. Mineral. 19, 25-34. 
Moyen, J.F., 2009. High Sr/Y and La/Yb ratios: the meaning of the "adakitic signature". Lithos, 112, 556574.

Muir, R. J., Ireland, T. R., Weaver, S. D., Bradshaw, J. D., 1996. Ion microprobe dating of Paleozoic granitoids: Devonian magmatism in New Zealand and correlations with Australia and Antarctica. Chemical Geology, 127(1-3), 191-210.

Norvick, M., Hutchinson, D.S., 1980. 1: 250,000 Geological series-explanatory notes: Aitape-Vanimo, Papua New Guinea. Department of Minerals and Energy, Geological Survey of Papua New Guinea, Port Moresby.

Page, R.W., 1976. Geochronology of igneous and metamorphic rocks in the New Guinea Highlands. Australian Bureau of Mineral Resources, Geology and Geophysics Bulletin 162, 117pp.

Palme, H., O'Neill, H.S.C., 2014. Cosmochemical estimates of mantle composition. Treatise on geochemistry, second edition 3, 1-39.

Panggabean, H., 1990. Geology of the Omba sheet area, Irian Jaya. Geological Survey of Indonesia, Directorate of Mineral Resources, Geological Research and Development Centre, Bandung.

Passchier, C.W., Trouw, R.A.J., 2005. Microtectonics. Springer, Berlin, pp. 366.

Paton, C., Hellstrom, J., Paul, B., Woodhead, J., Hergt, J., 2011. Iolite: Freeware for the visualisation and processing of mass spectrometric data. Journal of Analytical Atomic Spectrometry 26, 2508-2518.

Paton, C., Woodhead, J.D., Hellstrom, J.C., Hergt, J.M., Greig, A., Maas, R., 2010. Improved laser ablation U-Pb zircon geochronology through robust downhole fractionation correction. Geochemistry, Geophysics, Geosystems 11. 
Pearce, J.A., 1983. Role of the sub-continental lithosphere in magma genesis at active continental margins, in: Hawkesworth, C.J., Nurry, M.J. (Eds.), Continental Basalts and Mantle Xenoliths. Shiva Publishing, Nantwich, pp. 230-249.

Pennacchioni, G., Zucchi, E., 2013. High temperature fracturing and ductile deformation during cooling of a pluton: The Lake Edison granodiorite (Sierra Nevada batholith, California). Journal of Structural Geology $50,54-81$.

Petrus, J.A., Kamber, B.S., 2012. VizualAge: A Novel Approach to Laser Ablation ICP-MS U-Pb Geochronology Data Reduction. Geostandards and Geoanalytical Research 36, 247-270.

Phillips, E.R., 1980. On polygenetic myrmekite. Geological Magazine, 117, 29-36.

Pieters, P.E., Hakim, A.S., Atmawinata, S., 1990. Geologi lembar Ransiki, Irian Jaya. Geological Survey of Indonesia, Directorate of Mineral Resources, Geological Research and Development Centre, Bandung $81 \mathrm{pp}$.

Pieters, P.E., Hartono, U., Amri, C., 1989. Geologi lembar Mar, Irian Jaya. Geological Survey of Indonesia, Directorate of Mineral Resources, Geological Research and Development Centre, Bandung 62pp.

Pieters, P.E., Pigram, C.J., Trail, D.S., Dow, D.B., Ratman, N., Sukamto, R., 1983. The stratigraphy of western Irian Jaya. Bulletin Geological Research and Development Centre, Bandung 8, 14-48.

Pigram, C., Arnold, G.O., Griffin, T.J., 1977. Geology of the Minj 1:100 000 Sheet area. Geological Survey of Papua New Guinea Archives.

Pigram, C.J., Davies, H.L., 1987. Terranes and the accretion history of the New Guinea orogen. BMR Journal of Australian Geology and Geophysics 10, 193-212. 
898

Pigram, C.J., Panggabean, H., 1989. Geology of the Waghete Sheet area, Irian Jaya. Geological Survey of Indonesia, Directorate of Mineral Resources, Geological Research and Development Centre, Bandung.

Pigram, C.J., Sukanta, U., 1989. Geologi lembar Taminabuan, Irian Jaya. Geological Survey of Indonesia, Directorate of Mineral Resources, Geological Research and Development Centre, Bandung 51pp.

Pownall, J.M., Hall, R., Armstrong, R.A., Forster, M.A., 2014. Earth's youngest known ultrahigh-temperature granulites discovered on Seram, eastern Indonesia. Geology 42, 279-282.

Raymond, O., Sun, S. S., 1998. A comparison of Ordovician and Devonian magmatism in the eastern Lachlan Fold Belt: re-evaluating exploration targets. AGSO Res earch Newsletter, 28, 8-10.

Reiners, P.W., Ehlers, T.A., Zeitler, P.K., 2005. Past, present, and future of thermochronology. Reviews in Mineralogy and Geochemistry, 58, 1-18.

Richards, J.R., Wilmott, W.F., 1970. K-Ar age of biotites from Torres Strait. Australian Journal of Science 32.

Robinson, G.P., Harahap, B.H., Suparman, M., Bladon, G.M., 1990a. Geologi lembar Fak Fak, Irian Jaya. Geological Survey of Indonesia, Directorate of Mineral Resources, Geological Research and Development Centre, Bandung 51pp.

Robinson, G.P., Harahap, B.H., Tobing, S.L., Bladon, G.M., 1990b. Geologi lembar Pulau Karas-Pulau Adi, Irian Jaya. Geological Survey of Indonesia, Directorate of Mineral Resources, Geological Research and Development Centre, Bandung 39pp.

Robinson, G.P., Ratman, N., Pieters, P.E., 1990c. Geology of the Manokwari sheet area, Irian Jaya. Geological Survey of Indonesia, Directorate of Mineral Resources, Geological Research and Development Centre, Bandung. 
Robinson, G.P., Ryburn, R.J., Harahap, B.H., Tobing, S.L., Achdan, A., Bladon, G.M., Pieters, P.E., 1990 d. Geology of the Steenkool sheet area, Irian Jaya. Geological Survey of Indonesia, Directorate of Mineral Resources, Geological Research and Development Centre, Bandung.

Robinson, G.P., Ryburn, R.J., Harahap, B.H., Tobing, S.L., Bladon, G.M., Pieters, P.E., 1990e. Geology of the Kaimana Sheet area, Irian Jaya. Geological Survey of Indonesia, Directorate of Mineral Resources, Geological Research and Development Centre, Bandung.

Scaillet, B., Pichavant, M., Roux, J., 1995. Experimental Crystallization of Leucogranite Magmas. J. Petrol. $36,663-705$.

Shand, S.J., 1927. On the relations between silica, alumina, and the bases in eruptive rocks, considered as a means of classification. Geological Magazine 64, 446-449.

Sláma, J., Košler, J., Condon, D.J., Crowley, J.L., Gerdes, A., Hanchar, J.M., Horstwood, M.S.A., Morris, G.A., Nasdala, L., Norberg, N., 2008. Plešovice zircon-a new natural reference material for U-Pb and $\mathrm{Hf}$ isotopic microanalysis. Chemical Geology 249, 1-35.

Stipp, M., Stünitz, H., Heilbronner, R., Schmid, S.M., 2002a. Dynamic recrystallization of quartz: correlation between natural and experimental conditions. Geological Society, London, Special Publications 200, 171190.

Stipp, M., Stünitz, H., Heilbronner, R., Schmid, S.M., 2002b. The eastern Tonale fault zone: a 'natural laboratory' for crystal plastic deformation of quartz over a temperature range from 250 to $700 \mathrm{C}$. Journal of Structural Geology 24, 1861-1884.

Thirlwall, M.F., Singer, B.S., Marriner, G.F., 2000. 39 Ar-40 Ar ages and geochemistry of the basaltic shield stage of Tenerife, Canary Islands, Spain. Journal of Volcanology and Geothermal Research 103, 247-297. 
Thorpe, R.S., Francis, P.W., O’Callaghan, L., 1984. Relative roles of source composition, fractional crystallization and crustal contamination in the petrogenesis of Andean volcanic rocks. Philos. Trans. R. Soc. London A 310, 675-692.

Van Wyck, N., Williams, I.S., 2002. Age and provenance of basement metasediments from the Kubor and Bena Bena Blocks, central Highlands, Papua New Guinea: constraints on the tectonic evolution of the northern Australian cratonic margin. Australian Journal of Earth Sciences 49, 565-578.

Viete, D.R., Lister, G.S., 2017. On the significance of short-duration regional metamorphism. Journal of the Geological Society, 174, 377-392.

Visser, W.A., Hermes, J.J., 1962. Geological results of the exploration for oil in Netherlands New Guinea. Verhandelingen Koninklijk Nederlands Geologisch en Mijnbouwkundig Genootschap, Geologische Serie 20, 265pp.

Webb, M., White, L.T., 2016. Age and nature of Triassic magmatism in the Netoni Intrusive Complex, West Papua, Indonesia. Journal of Asian Earth Sciences 132, 58-74.

White, L.T., Morse, M.P., Lister, G.S., 2014. Lithospheric-scale structures in New Guinea and their control on the location of gold and copper deposits. Solid Earth 5, 163-179 (doi:10.5194/se-5-163-2014)

Williams, I.S., 2001. Response of detrital zircon and monazite, and their U-Pb isotopic systems, to regional metamorphism and host-rock partial melting, Cooma Complex, southeastern Australia. Australian Journal of Earth Sciences 48, 557-580.

Woodland, B. G., 1963. A petrographic study of thermally metamorphosed pelitic rocks in the Burke area, northeastern Vermont. American Journal of Science 261, 354-375.

Zen, E.A., 1986. Aluminum enrichment in silicate melts by fractional crystallization: some mineralogic and petrographic constraints. Journal of Petrology 27, 1095-1117. 
Zen, E.A., 1988. Phase relations of peraluminous granitic rocks and their petrogenetic implications. Annual Review of Earth and Planetary Sciences 16, 21-51.

984

985

\section{TABLE CAPTIONS}

Table 1. Data from previous studies on igneous units in NW New Guinea.

\section{FIGURE CAPTIONS}

Figure 1. Overview of the study area. A: Tectonic map of eastern Indonesia and New Guinea. The red frame delineates the location of subfigure B. B: Simplified geological map of NW New Guinea specifying granitoid intrusions in the area and respective sample locations and numbers. The red rectangle delineates the location of the geological map of Figure 2 .

Figure 2. Geological map of the NE Kemum Basement High specifying sample locations and numbers. Sampling locations for the Wasiani Granite (alluvial samples BJ92, and BJ93), the Kwok Granite (in-situ sample BJ67), and the Momi Gabbro are indicated. Bold numerals refer to sample numbers (shorthand for BJXXX, where XXX is the sample number; 5B and 6D refer to samples LW13-5B and LW13-6D, respectively); regular numerals refer to waypoint numbers (shorthand for BH15-YYY, where YYY is the waypoint number; exceptions BH14-16, BH14-17 and BH14-24 are indicated). Geology modified from Pieters et al. (1990) and Robinson et al. (1990c). Gb: Gabbro, Gt: Granite.

Figure 3. Granitoid exposures and field relationships in the E Kemum Basement High. A: Thin quartzofeldspathic sill offset by normal-separation faults (red lines) (waypoint BH15-083). B: Pegmatite dyke obliquely crosscutting metasedimentary basement rocks (waypoint BH15-142). After intrusion, the dyke was first folded and later boudinaged. Note the narrow dark aureole of contact metamorphism adjacent to the intrusion. C: Mingling indicated by cuspate-lobate boundaries (left) and cross-cutting relationships indicated by straight and parallel boundaries (right) between the Momi Diorite (blue line) and the Anggi Granite. The Anggi Granite contains abundant country-rock xenoliths (dashed white line). The outcrop is cut by later normal-separation faults (red lines) (waypoint BH15-171). D: Pinch-and-swell structures of metapsammitic to metapelitic country rock xenoliths (dashed white line) in the Anggi 
1011

1012

1013

1014

1015

1016

1017

1018

1019

1020

1021

1022

1023

1024

1025

1026

1027

1028

Granite offset by normal-separation faults (red lines). The blue line denotes the contact of the Anggi Granite with a metacalcareous country rock (waypoint BH15-174).

Figure 4. Representative photomicrographs of selected Devonian-Carboniferous (A-F, blue) and Permian-Triassic granitoids (G-L, green). B: The Ngemona Granite with tourmaline (trm) overgrown by garnet (gt) and muscovite (mu) surrounded by quartz (qtz), PPL (sample BJ53). B: The Wasiani Granite with biotite next to sericitised plagioclase (plag), microcline (mic), and quartz; note the large zircon crystal (blue arrow), PPL (sample BJ92). C: Monzonite associated with the Wasiani Granite showing a glomerocryst of K-feldspar (kfs), amphibole, and chlorite, surrounded by K-feldspar in a fine-grained groundmass of amphibole (blue arrow), chlorite, and K-feldspar, PPL (sample BJ93). D: Pegmatite associated with the Wasiani Granite showing a broken crystal of kyanite (ky), partially replaced by white mica at the top left corner (blue arrow) surrounded by quartz, muscovite, and subordinate plagioclase, PPL (sample BJ104A). E: Kwok Granite with garnet, sericitised feldspar, quartz and biotite altering to sillimanite (fibrolite, sill), PPL (sample BJ67). F: Melaiurna Rhyolite with phenocrysts of embayed quartz, altered K-feldspar, saussuritised plagioclase, and bent muscovite (blue arrows) in a microcrystalline groundmass, PPL (sample BJ22). G: A vein of secondary muscovite (green arrow) in a brittlely deformed pegmatite containing plagioclase, microcline, and quartz associated with the Wariki Granodiorite, XPL (sample BJ01). Note the kinking and deformation twinning in plagioclase. H: Granite of the Anggi Intrusive Complex (AIC) showing garnet overgrown by biotite (green arrow) next to quartz and feldspar, PPL (sample BJ138). I: Diorite of the Anggi Intrusive Complex with partially sericitised plagioclase surrounding glomerocrysts of chlorite (alteration product of biotite), associated with abundant titanite (green arrow), PPL (sample BJ134). J: High-alumina diorite associated with the Anggi Intrusive Complex showing metastable hornblende (hbl) reacting to chlorite (bottom left) and garnet associated with biotite (green arrow); plagioclase is the dominating felsic mineral, PPL (sample LW13-6D). K: Momi Gabbro with abundant augitic pyroxene (cpx) overgrown by rims of amphibole (uralite, green arrows), plagioclase laths, and minor biotite and quartz, XPL (sample LW13-5B). L: Kwatisore Granite with hornblende and biotite surrounded by predominantly plagioclase, K-feldspar, and quartz, PPL (sample 12JD339A). Unit names are indicated; Gb: Gabbro, Gdt: Granodiorite, Gt: Granite. 
Figure 5. Microstructures of the granitoids. A: Fresh rims of plagioclase around older, partly sericitised plagioclase cores (core-and-mantle structures, blue arrows) where in contact with microcline; bulging recrystallization between microcline grains (red arrow) and grain boundary migration recrystallization between quartz and microcline (pinning, green arrow); trm: tourmaline, XPL. B: Myrmekite (blue arrow) in plagioclase (plag) where the mineral replaced microcline (mic) and consertal texture between quartz (qtz) and microcline (red arrow), XPL. C: Preferential growth of fibrolite microlites on a biotite crystal (bt), gt: garnet, PPL. D: Preferential replacement of muscovite (mu) with symplectites along $\{001\}$ cleavage planes where in contact with plagioclase, but not where in contact with quartz, XPL. E: Large quartz grain with chessboard subgrains replaced by smaller quartz grains showing grain boundary migration and minor subgrain rotation recrystallization, XPL. F: Flame perthite (blue arrows), circular quartz exsolution features, and subordinate bulbous myrmekites (red arrow) in microcline, XPL. Sample numbers are indicated; Gdt: Granodiorite, Gt: Granite.

Figure 6. Migmatites observed in situ in the E Kemum Basement High. A: Pockets of neosome in an incipient migmatite associated with the Kwok Granite. B: Photomicrograph of the melanosome of A, showing restitic cordierite (crd) overgrowing sillimanite (red arrow), surrounded by quartz (qtz), biotite (bt), and plagioclase (blue arrow). C: Schlieric migmatite associated with the Anggi Intrusive Complex. D: Photomicrograph of $\mathrm{C}$ showing the melanosome with biotite and metastable muscovite $(\mathrm{mu})$ in contact with large neoblasts of plagioclase (plag) and quartz representing the neosome. Sample numbers and sampling localities are indicated.

Figure 7. Harker-type variation diagrams for major elements of the granitoids of NW New Guinea. Iron is given as total ferrous iron $\left(\mathrm{FeO}_{\mathrm{t}}\right)$. Sample BJ83 is not dated (black triangle). Data for the Netoni Intrusive Complex (IC) are from Webb and White (2016). Gb: Gabbro, Gt: Granite, Gdt: Granodiorite, IC: Intrusive Complex, Ry: Rhyolite.

Figure 8. Peraluminosity of granitoids from NW New Guinea. A: Aluminium Saturation Index (ASI) vs. A/NK plot (Shand, 1927). B: AFM triangle for granitoids (Miller, 1985); Ps: strongly peraluminous, Pw: weakly peraluminous, Mw: weakly metaluminous. als: aluminosilicate, mu: muscovite, crd: cordierite, gt: garnet, bt: biotite, hbl: hornblende. 
Figure 9. Trace element spidergrams normalised to the primitive mantle of Palme and O’Neill (2014). The area shaded in grey delineates the composition of higher-grade basement rocks of the Kemum Formation ( $n=10$ ); the area surrounded by a dashed line represents the composition of the Netoni Intrusive Complex (Webb and White, 2016).

Figure 10. Summary of LA-ICP-MS U-Pb zircon data and ages for samples of Devonian-Carboniferous age.

Vertical bars represent the uncertainty (propagated 2s) of individual measurements. Filled bars represent measurements used to calculate mean ages; empty bars represent rejected measurements. The coloured line and ranges represent the weighted mean and both internal and propagated uncertainty $(95 \%=1.96$ SDOM, standard deviation of the mean) of each sample.

Figure 11. Summary of LA-ICP-MS U-Pb zircon data and ages for samples of Permian-Triassic age (green). Symbology as in Figure 10.

Figure 12. Representative CL images of zircon textures observed (A-D) and of selected examples of rounded and concordant inherited cores (E-H). Many samples contain zircons with magmatic growth zones (A, C, E, F, G, and H), while the zircons of some samples (especially the Ngemona, Kwok, and Wasiani granites) are not zoned and often CL-bright (B); BJ93 is additionally characterised by angular and xenomorph crystal shapes (B). Growth-zoned zircons from the Wariki Granodiorite were fractured and subsequently 'cemented' with later (metamorphic?) zircon overgrowths (C). Care was taken to ablate only the magmatic fragments of the zircons. Some evolved or pegmatitic samples (BJ08, BJ09, and BJ80) are characterised by uniformly CL-dark zircons (D). ${ }^{207} \mathrm{~Pb} /{ }^{206} \mathrm{~Pb}$ ages are reported for cores $>1000 \mathrm{Ma}(\mathrm{F}-\mathrm{H})$; note the large error of a core of sample LW13-5B (G). Ages in square brackets were not used to calculate

Figure 13. Pre-Cenozoic granitoids in eastern Indonesia and Papua New Guinea. A: Global plate tectonic reconstruction of the Late Triassic (modified from Metcalfe (2013)). The red circle marks the approximate location of NW New Guinea at the time. B: Current map of dated pre-Cenozoic granitoids. C: Graphical 

including uncertainties, MSWD, and number of analyses.

\section{CAPTIONS TO THE SUPPLEMENTARY DATA FILES}

Supplementary Data File 2. Waypoints and samples used in this study. granitoids. study.

Supplementary Data File 9. Compilation of LA-ICP-MS data.

numbers correspond to the locations shown in B. Many of the cited publications are difficult to access, but the data has been summarised by Davies (1990). Geological time scale after Gradstein et al. (2012).

Supplementary Data File 1. Granitoids of NW New Guinea: A literature review.

Supplementary Data File 3. Qualitative modal composition of granitoid samples studied in thin section.

Supplementary Data File 4. Scanning electron microscope cathodoluminescence images of individual samples analysed with LA-ICP-MS, indicating laser spots and integration numbers.

Supplementary Data File 5. U-Pb zircon LA-ICP-MS measurement parameters.

Supplementary Data File 6. Methodology and data treatment for U-Pb zircon dating.

Supplementary Data File 7. Petrography of the Devonian-Carboniferous and the Permian-Triassic

Supplementary Data File 8. XRF bulk rock analyses, CIPW norms, and ASI and A/CNK values used in this

Supplementary Data File 10. Tera-Wasserburg diagrams for the samples presented in this study. 
Submitted to Lithos

1130 Supplementary Data File 12. Change of crystallisation age with increasing discordance for samples BJ08, 1131 BJ09, and BJ80. 


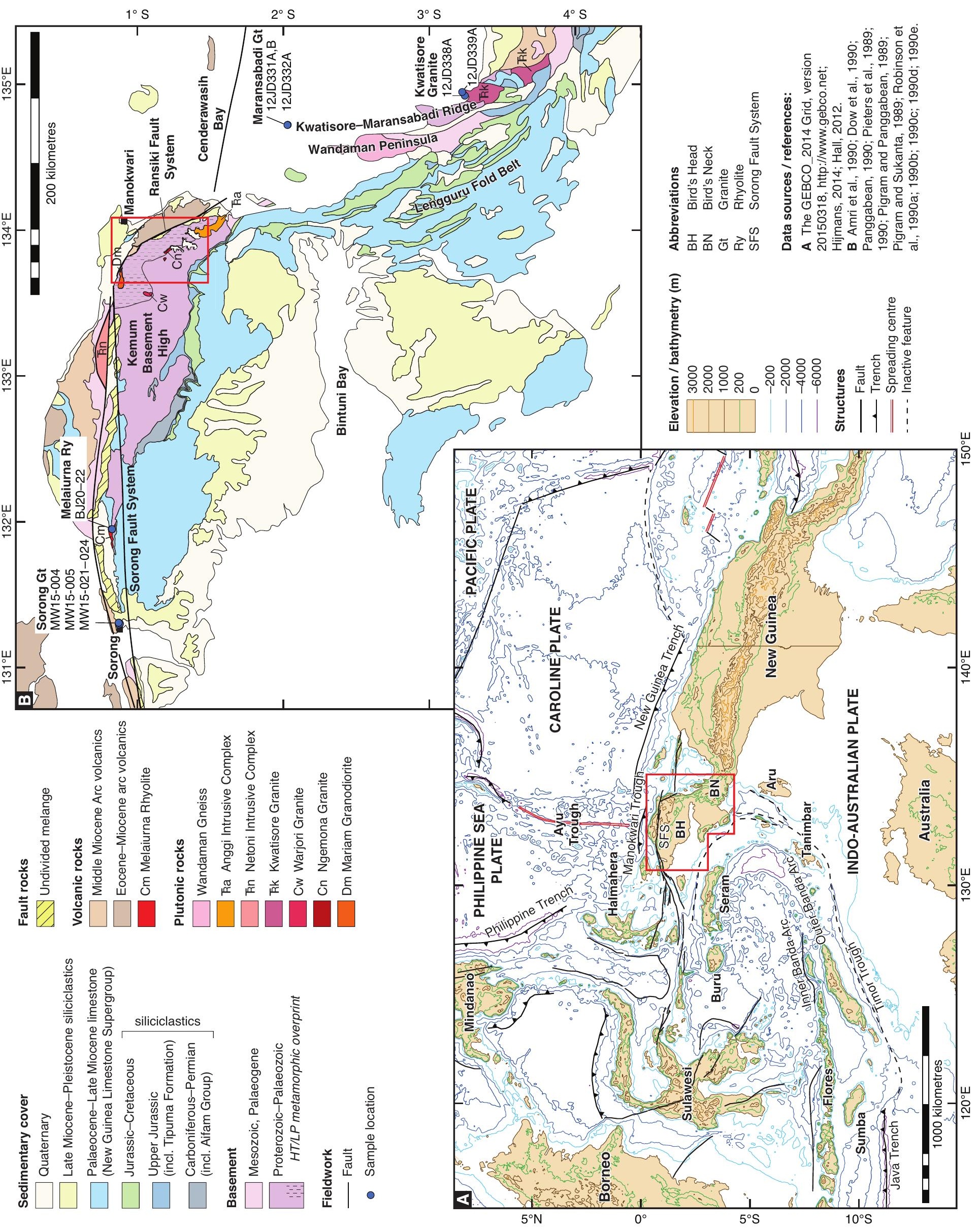




\section{Samples and Waypoints}

Waypoint

- Sample, undated

- Sample, Permian-Triassic

- Sample, Carboniferous

- Sample, Devonian-Carboniferous

(O) Float sample, scree sample Tracks

Fault (observed, approximate, covered) Q Quaternary

\section{RANSIKI FAULT SYSTEM}

Tmle Lembai Diorite RFx Undivided melange

\section{ARFAK BLOCK}

Qpm Manokwari Formation TQb Befoor Formation Tmma Maruni Limestone Tema Arfak Volcanics

\section{KEMUM BLOCK}

Sedimentary cover

Qpme Menyambo Formation

TQb Befoor Formation

TQw Wai Formation

New Guinea Limestone

Kais Limestone

Sirga Formation

Faumai Limestone

Jass Formation

RJt Tipuma Formation

\section{Intrusive rocks}

${ }_{+}^{+}$Ra Anggi Granite

$+{ }_{+}^{+}$Rw Wariki Granodiorite

${ }_{+}^{+}$Cn Ngemona Granite

$+{ }_{+}^{+} \mathrm{Dm}$ Mariam Granodiorite

Basement

i

SDk Kemum Formation

Biotite zone

Andalusite zone

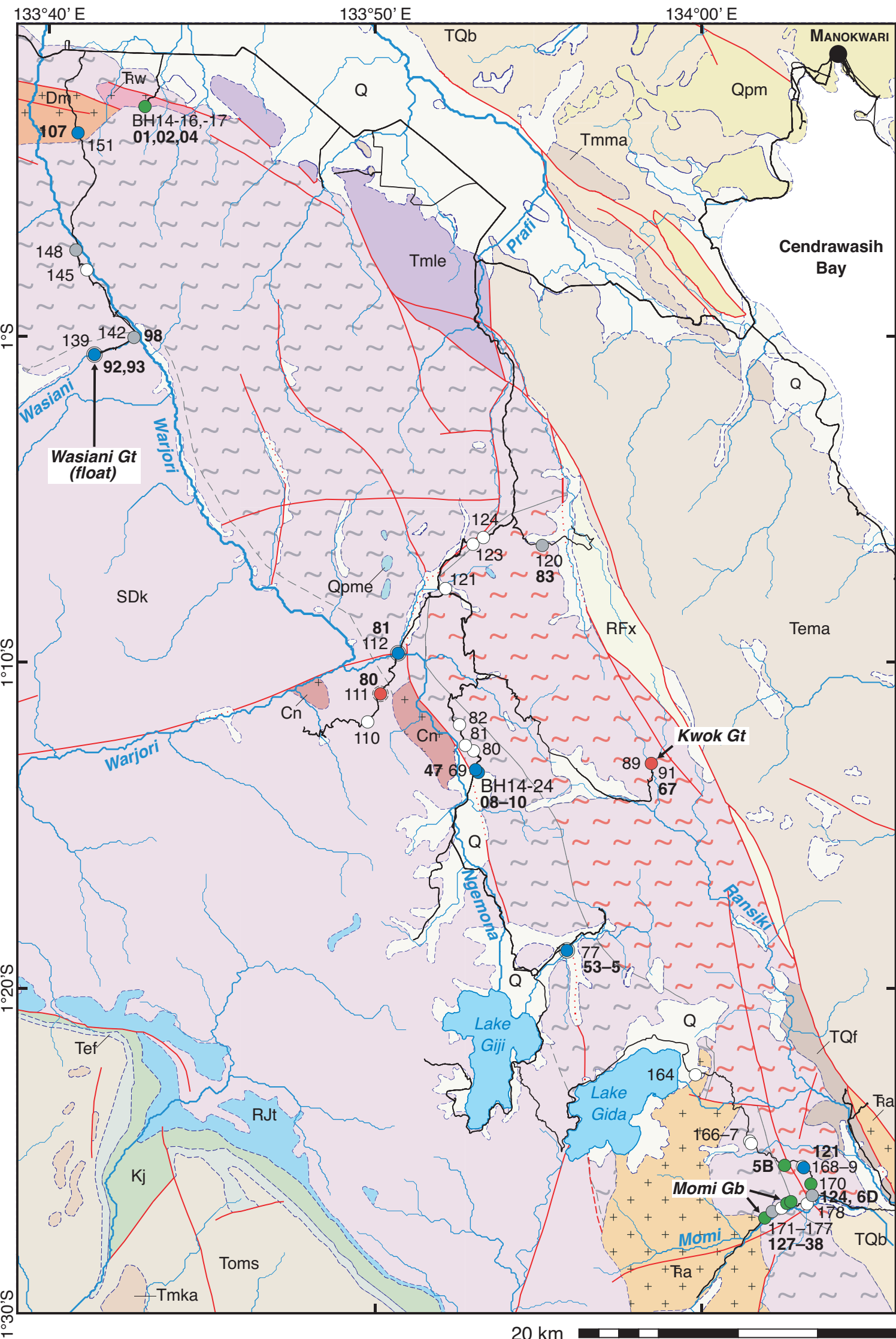


Click here to download high resolution image
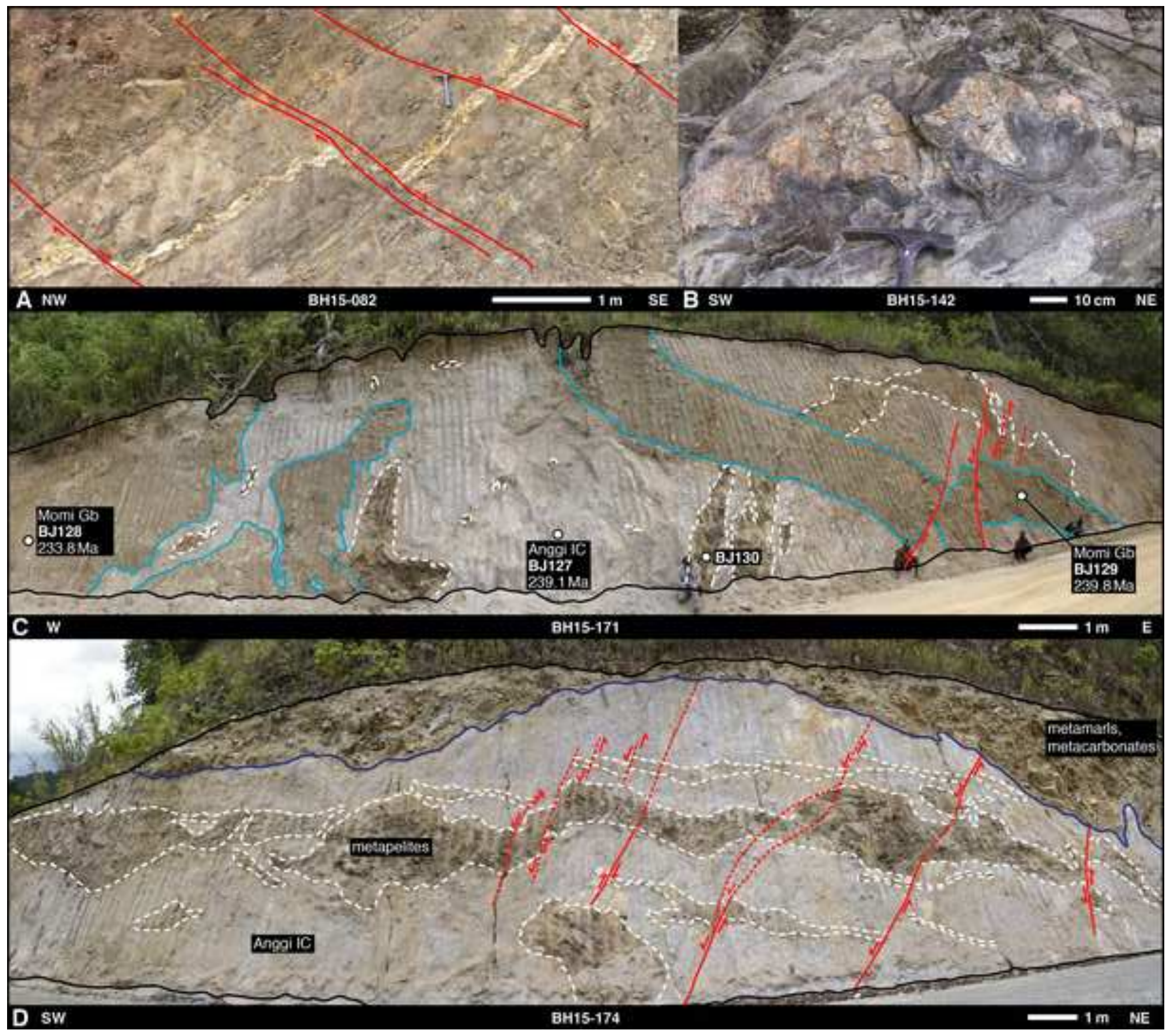


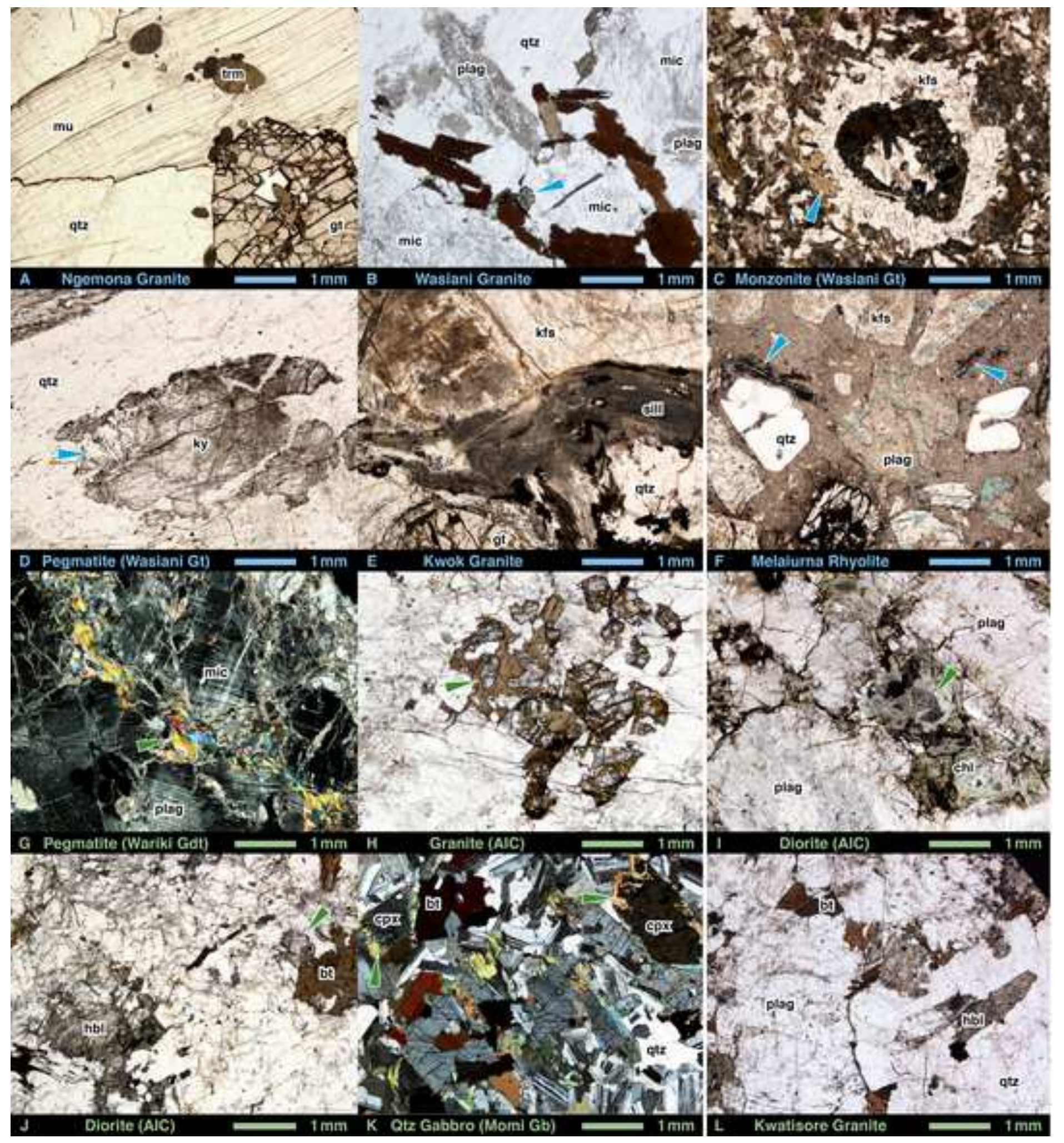



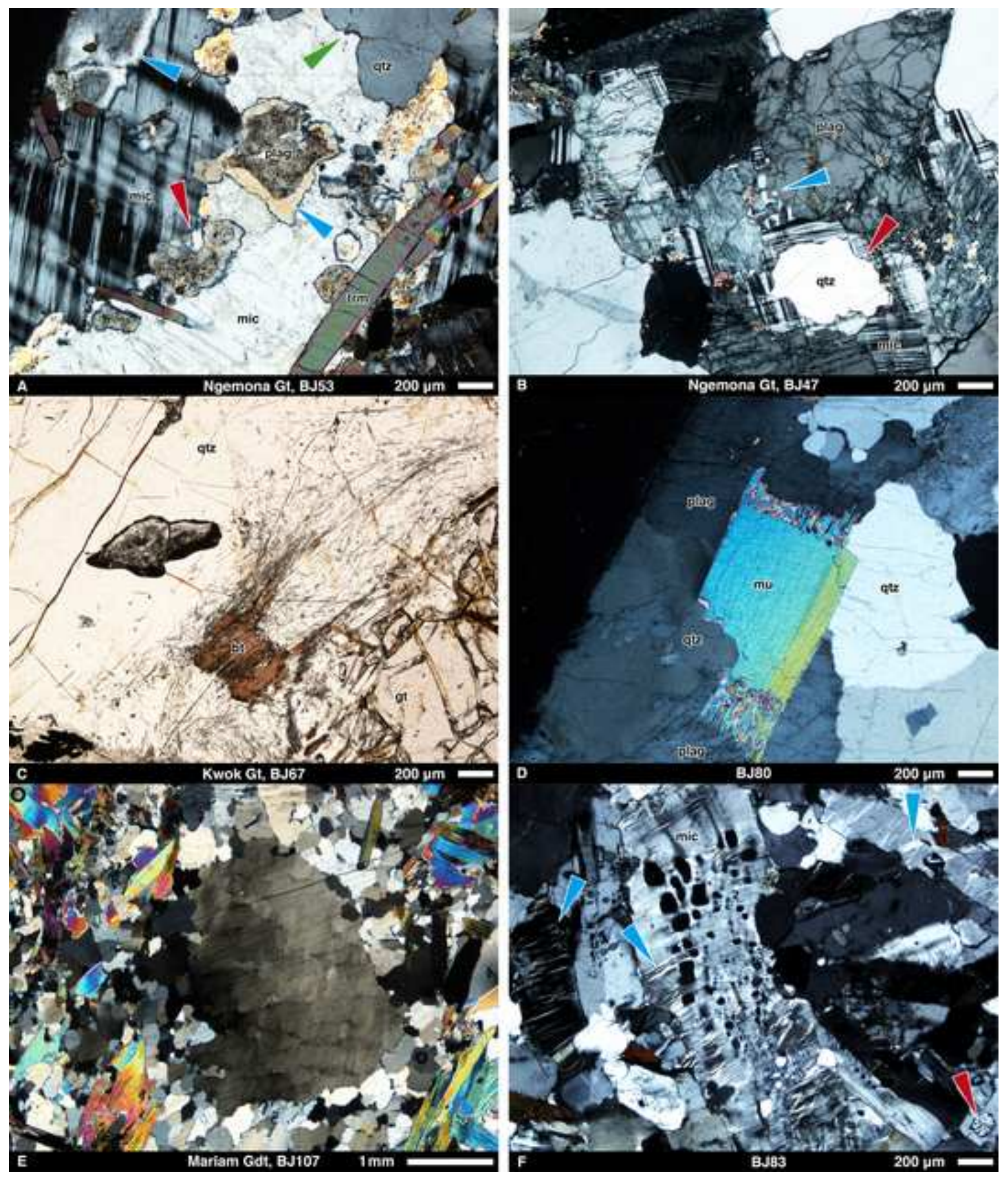
Click here to download high resolution image

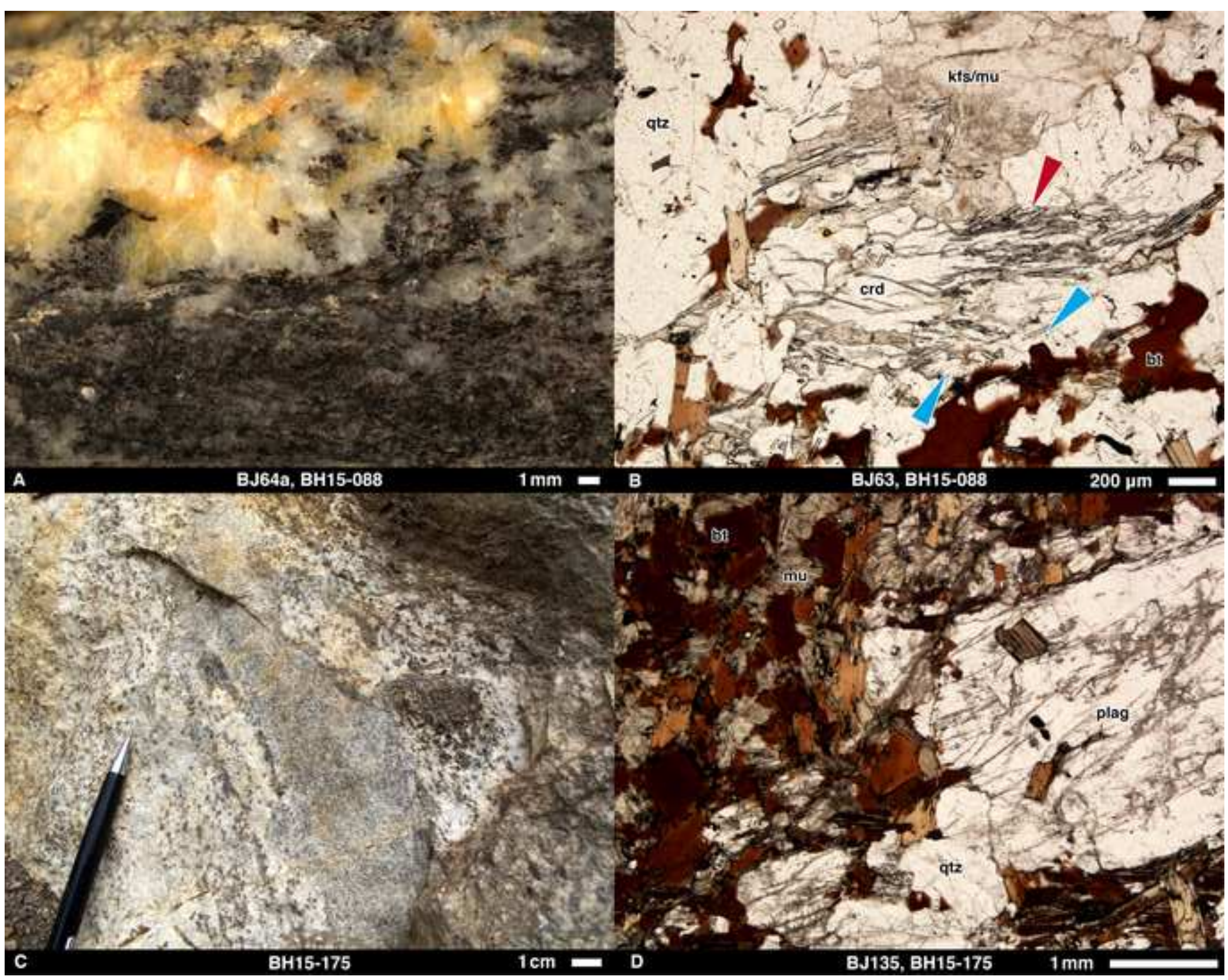




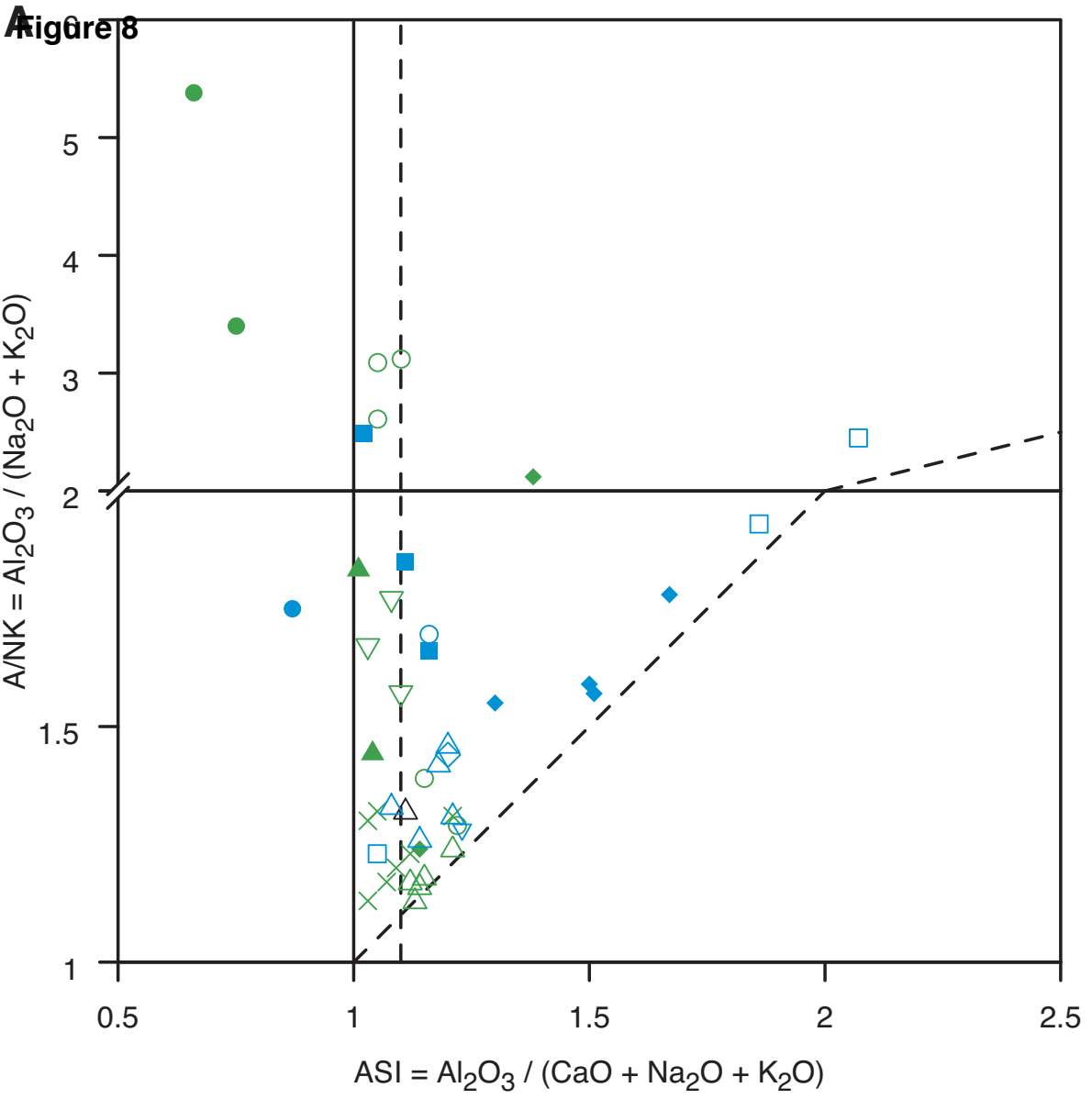

B

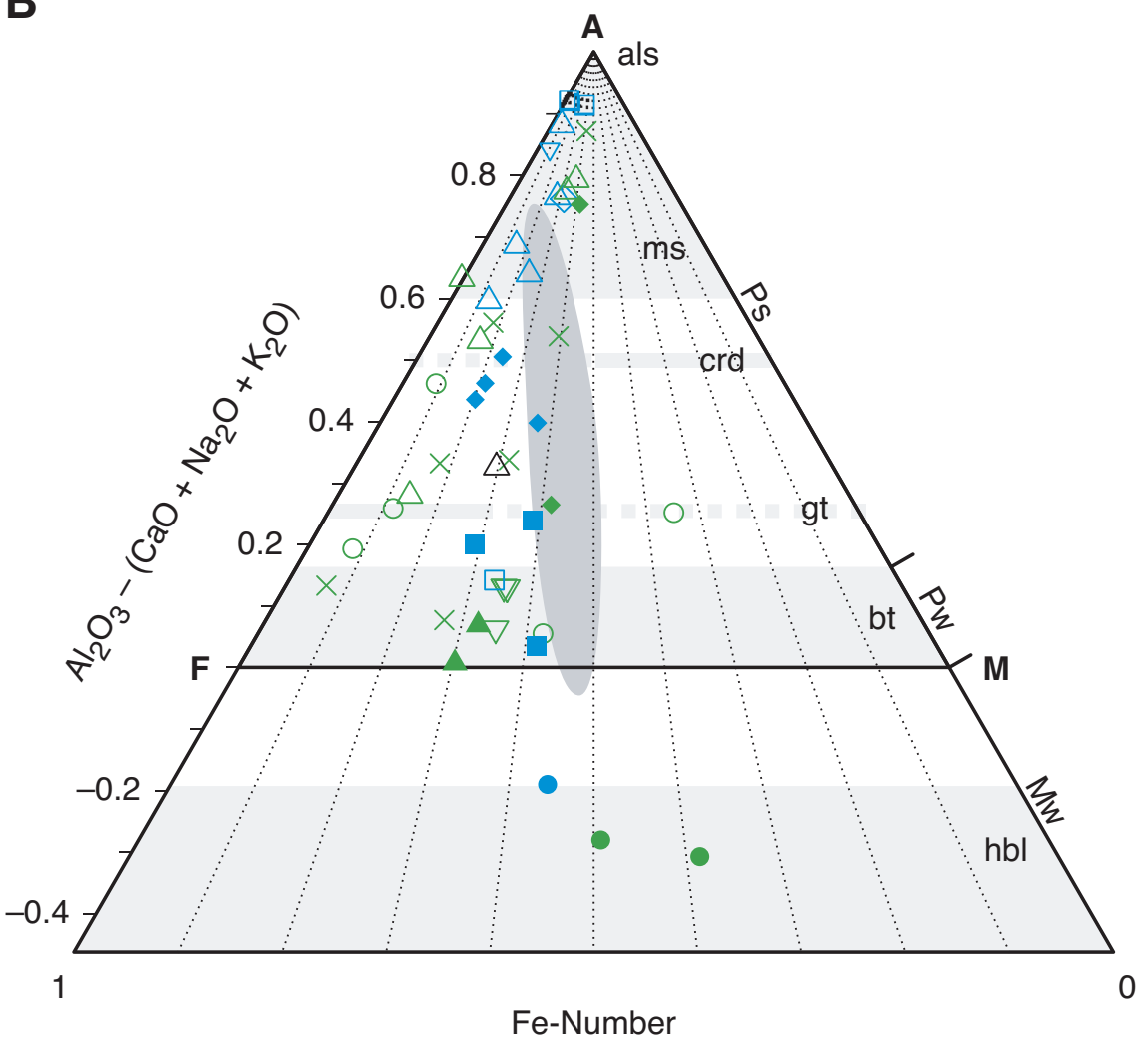

\section{Devonian-Carboniferous}

$\triangle$ Ngemona Gt

$\square$ Wasiani Gt

- Mariam Gdt

$\diamond$ Kwok Gt

- Melaiurna Ry

- BJ93

○ BJ10

$\nabla \mathrm{BJ} 80$
Permian-Triassic not dated

$\triangle$ Sorong Gt $\quad \triangle$ BJ83

$\nabla$ Maransabadi Gt

$\triangle$ Kwatisore Gt

$\times$ Netoni IC

- Wariki Gdt

- Anggi IC

- Momi Gb
Basement rocks

Kemum Formation $(\mathrm{n}=8)$ 


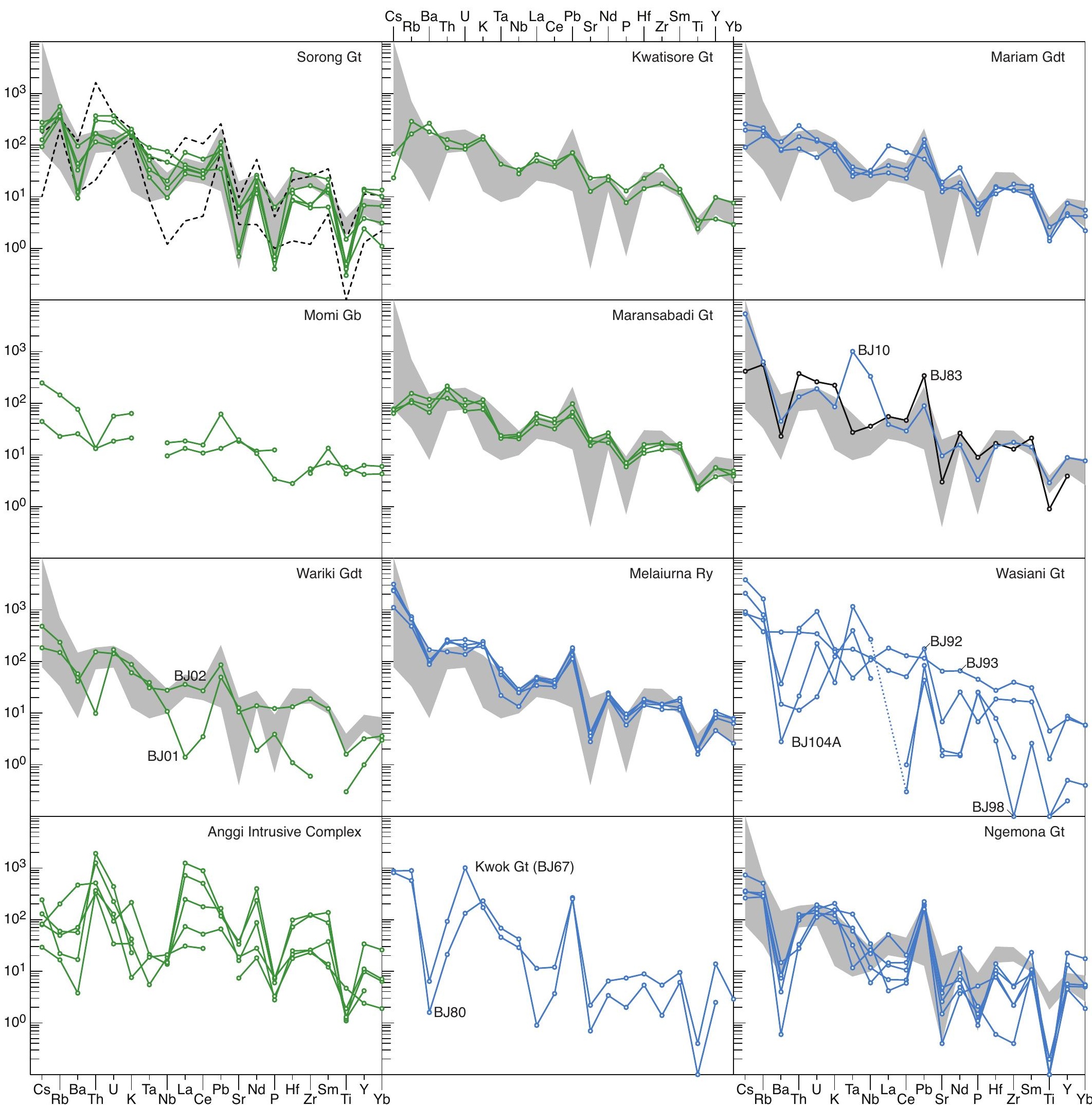




\section{General features}

A BJ124 Anggi Intrusive Complex

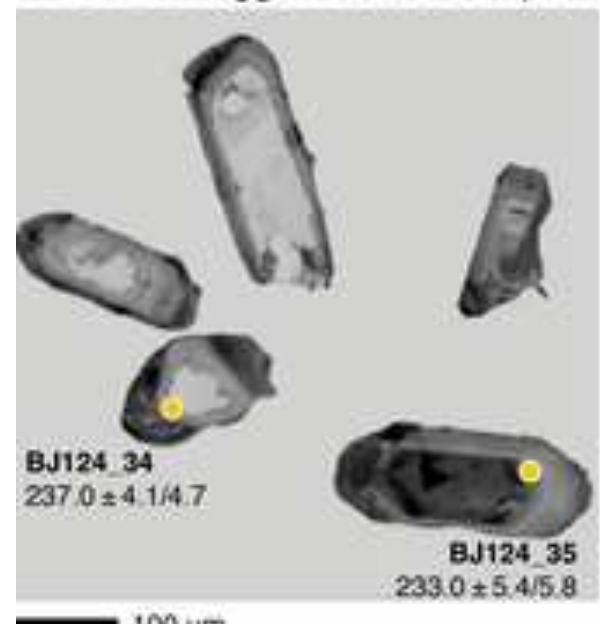

$100 \mu \mathrm{m}$

\section{Inherited cores}

E BJ22 Melaiuma Rhyolite

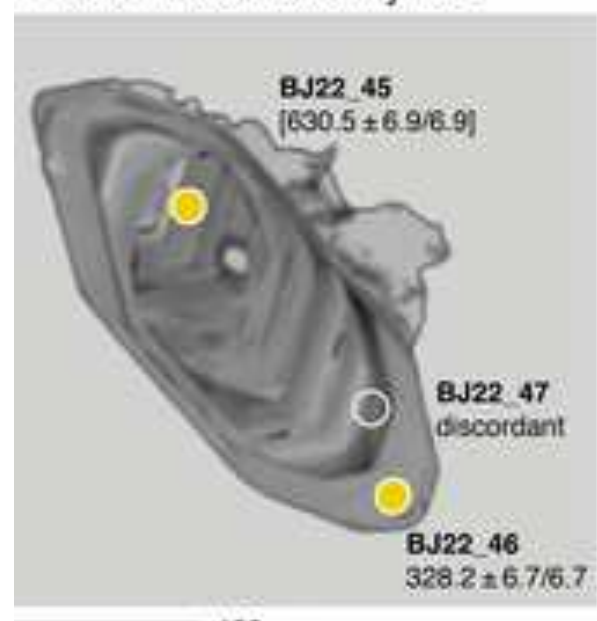

B BJ93 Monzonite

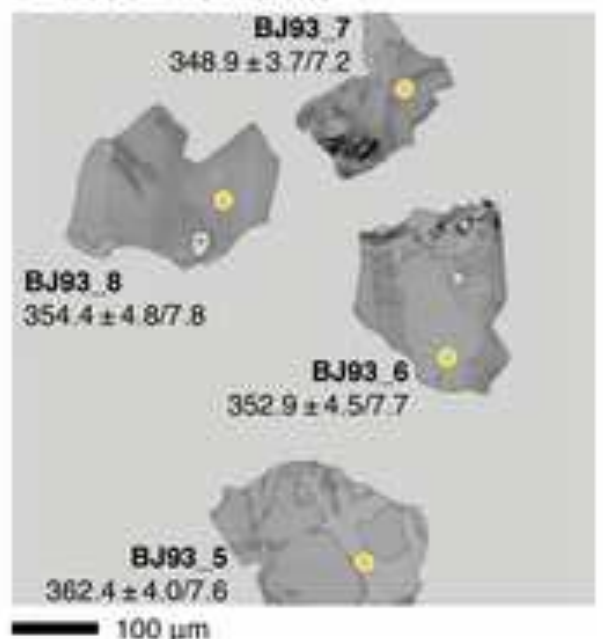

F BJ10 Diorite (unassigned)

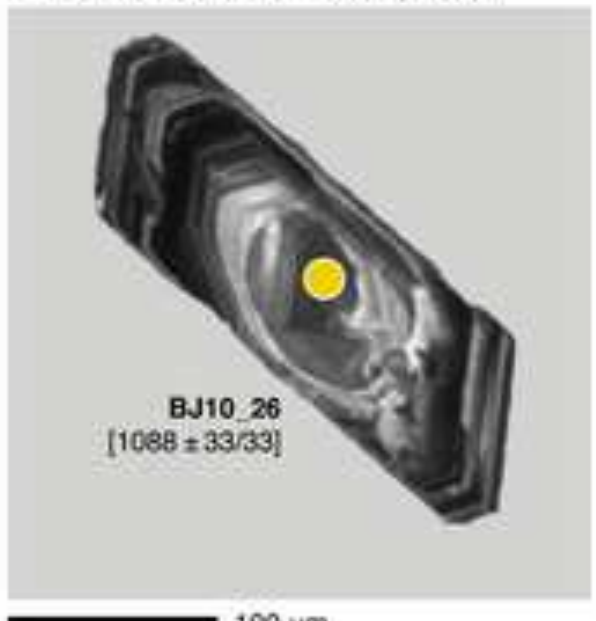

C BJ02 Wariki Granodiorite

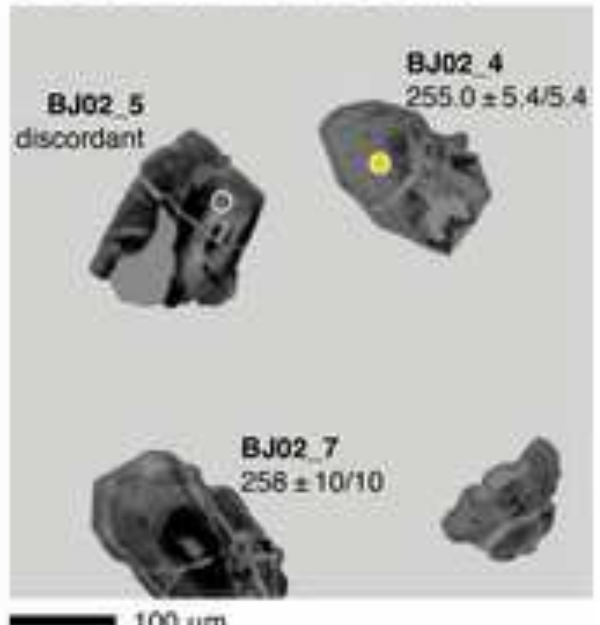

$100 \mu \mathrm{m}$

G LW13-5B Momi Gabbro

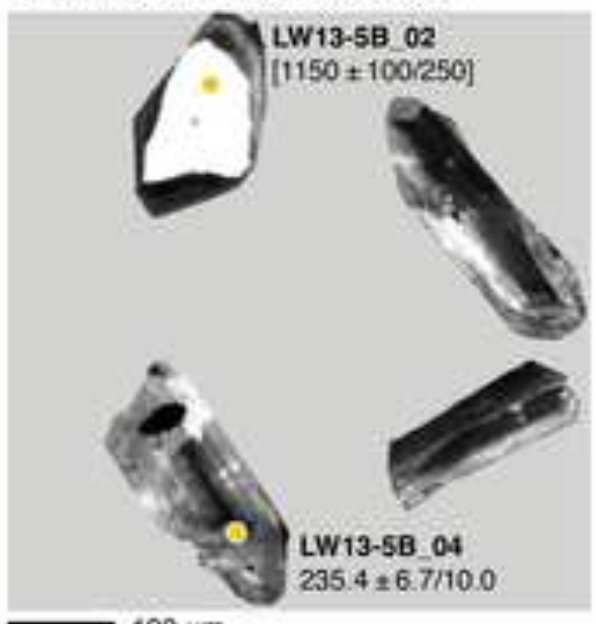

D BJ08 Ngemona Granite

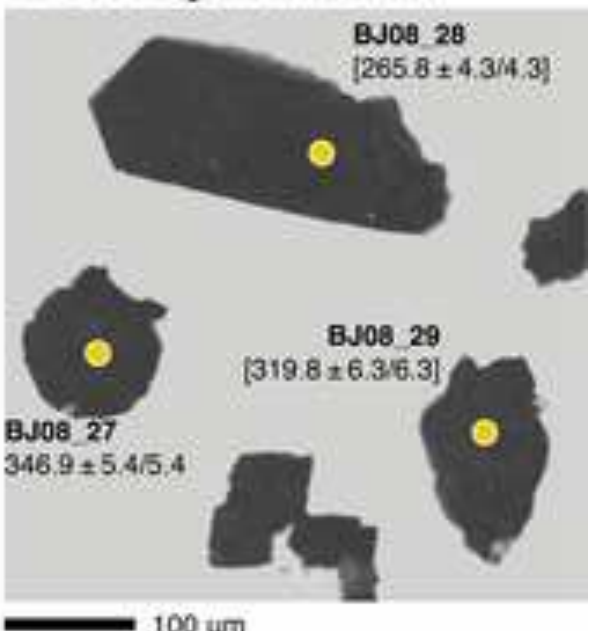

$100 \mu \mathrm{m}$

H BJ127 Anggi Intrusive Complex

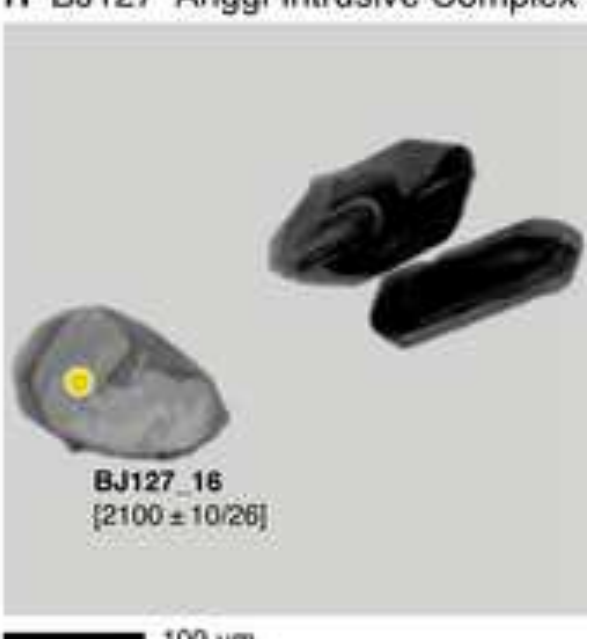




\section{$\sim 205 \mathrm{Ma}$}

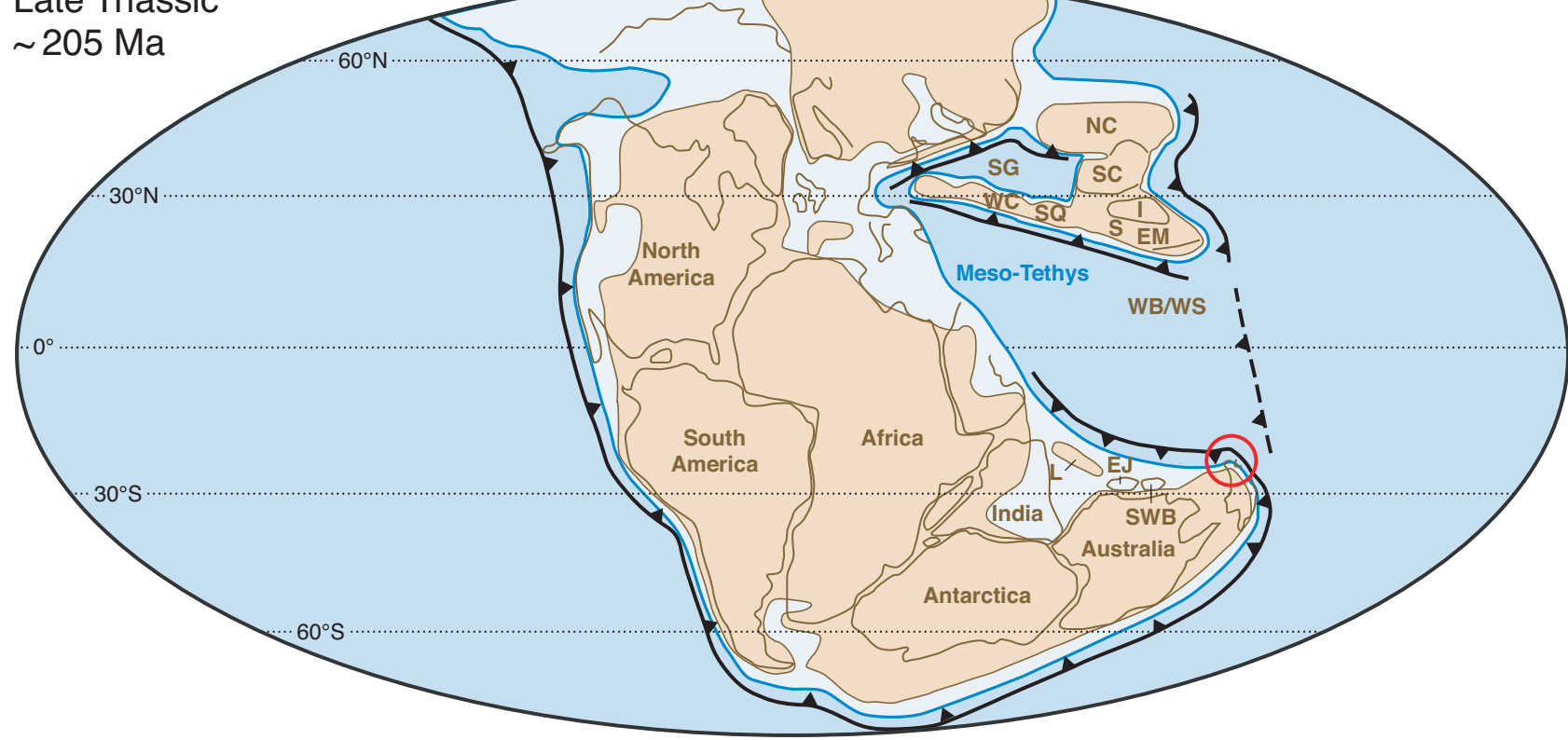

East Java/West Sulawesi

EM East Malaya block

I Indochina block

L Lhasa Terrane

NC North China

S Sibumasu Terrane

SC South China

SG Songpan Ganzi

SQ South Qiangtang

SWB South West Borneo

WB West Burma

WC West Cimmerian

WS West Sumatra block

Shallow sea

Deep sea
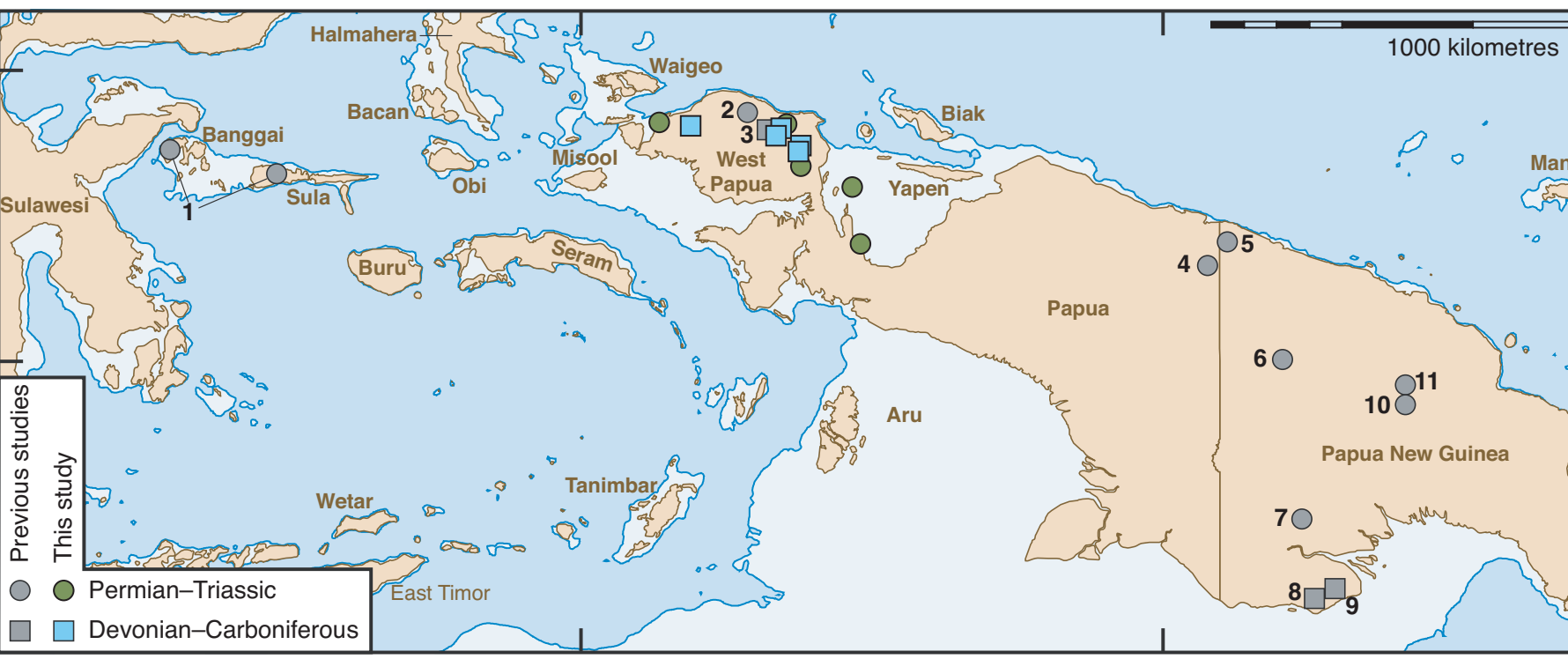

$11213,231,242 \mathrm{Ma} \quad \mathrm{O}$ 2 215-247 Ma

$5216,240 \mathrm{Ma}$ 223-239 Ma 224-236 Ma

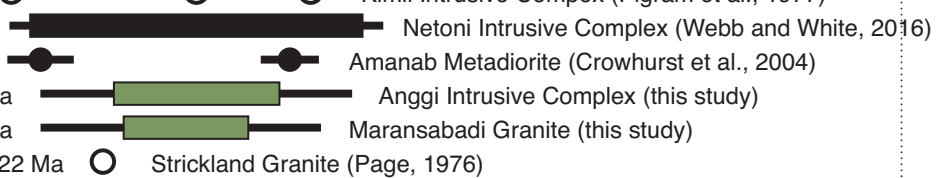

O O Kimil Intrusive Compex (Pigram et al., 1977)

$6222 \mathrm{Ma} O \quad$ Strickland Granite (Page, 1976)

228-240 Ma Momi Gabbro (this study)

226-258 Ma Wariki Granodiorite (Bladon, 1988)

227-248 Ma Anggi Granite (Bladon, 1988)

231-233 Ma Kwatisore Granite (this study)

$1226-244 \mathrm{Ma}$ ¿ Banggai-Sula (Decker et al., 2017)

$1230-260 \mathrm{Ma}$ Banggai-Sula (Ferdian et al., 2012)

240-244 Ma Sorong Granite (this study)

$7236 \mathrm{Ma} O$ Granite in Amira 1 well (Harding et al., 1969)

$10241 \mathrm{Ma}-$ Kubor Intrusive Complex (Van Wyck and Williams, 2002)

$4 \quad 242-257 \mathrm{Ma} \square$ Border Mts. granitoids (Norvik and Hutchison, 1980)

$8300 \mathrm{Ma} O$ Mabaduan Granite (Richards and Willmott, 1970) Melaiurna Rhyolite (this study) Kwok Granite (this study) 328-329 Ma $329 \mathrm{Ma}$ Melaiurna Granite (Bladon, 1988) $\square$ 324-328 Ma

Ngemona Granite (this study) Wasiani Granite (monzonite BJ93) (this study) $\quad 352 \mathrm{Ma}$ 
Table 1 Data from previous studies on igneous units in NW New Guinea.

\begin{tabular}{|c|c|c|c|c|c|c|}
\hline Unit & Description & Relations & Age (Ma) & $\mathrm{N}$ & System & Reference \\
\hline Maransabadi Gt & $\begin{array}{l}\text { Biotite granite or granodiorite, diorite, gabbro, rare tourmaline } \\
\text { pegmatite }\end{array}$ & $\begin{array}{l}\text { Emplaced in undifferentiated } \\
\text { metasediments }\end{array}$ & 278,231 & $2^{\mathrm{a}}$ & $\mathrm{K}-\mathrm{Ar}$ & $\begin{array}{l}\text { Bladon (1988), Pieters et al. (1983), } \\
\text { Robinson et al. (1990d) }\end{array}$ \\
\hline Kwatisore Gt & Grey biotite granite, pink two-feldspar granite & $\begin{array}{l}\text { Intrudes and in faulted contact } \\
\text { with undifferentiated } \\
\text { metasediments; overlain by } \\
\text { Miocene limestone and quartz } \\
\text { sandstone }\end{array}$ & $197 \pm 3$ & $1^{\mathrm{a}}$ & $\mathrm{K}-\mathrm{Ar}$ & $\begin{array}{l}\text { Bladon (1988), Pieters et al. (1983), } \\
\text { Robinson et al. (1990e) }\end{array}$ \\
\hline Sorong Gt & $\begin{array}{l}\text { Red, equigranular granite, minor aplite, quartz veins; commonly } \\
\text { sheared }\end{array}$ & $\begin{array}{l}\text { In faulted contact with other } \\
\text { units in the Sorong Fault System }\end{array}$ & $224 \pm 11$ & $1^{\mathrm{b}}$ & $\mathrm{K}-\mathrm{Ar}$ & Amri et al. (1990) \\
\hline $\begin{array}{l}\text { Netoni } \\
\text { Intrusive } \\
\text { Complex }\end{array}$ & $\begin{array}{l}\text { Granite, granodiorite, quartz monzonite, and syenite with minor } \\
\text { diorite, quartz diorite, and pegmatite; xenoliths of gabbro, } \\
\text { diorite, amphibolite, and hornblende schist }\end{array}$ & $\begin{array}{l}\text { Fault-bounded fragment (facoid) } \\
\text { in the Sorong Fault System }\end{array}$ & $256-206$ & 5 & $\mathrm{U}-\mathrm{Pb}$ & $\begin{array}{l}\text { Bladon (1988), Pieters et al., (1989), } \\
\text { Webb and White (2016) }\end{array}$ \\
\hline Wariki Gdt & $\begin{array}{l}\text { Course-grained granodiorite with quartz, plagioclase, K-feldspar, } \\
\text { biotite, and minor muscovite, accessory tourmaline, apatite, } \\
\text { zircon, garnet, and allanite; subordinate monzogranite and } \\
\text { tonalite; fine-grained, biotite-rich schlieren and xenoliths are } \\
\text { common; locally cut by pegmatite and aplite dykes; variably } \\
\text { deformed (cohesive cataclasites to ultramylonites) }\end{array}$ & $\begin{array}{l}\text { Plutons in mainly faulted contact } \\
\text { with Kemum Fm }\end{array}$ & $258-222$ & $6^{c}$ & $\mathrm{~K}-\mathrm{Ar}$ & Bladon (1988), Robinson et al. (1990c) \\
\hline Anggi Gt ${ }^{\mathrm{d}}$ & $\begin{array}{l}\text { Biotite and biotite-muscovite granite, subordinate quartz } \\
\text { diorite; medium-grained; xenoliths and roof pendants of country } \\
\text { rock as well as late-stage aplite and pegmatite dykes common; } \\
\text { biotite-rich (mesocratic) xenoliths common along margins }\end{array}$ & $\begin{array}{l}\text { Intrudes and in faulted contact } \\
\text { with Kemum Fm; phacoids in } \\
\text { Ransiki Fault System }\end{array}$ & $248-225$ & $3^{a}$ & $\mathrm{~K}-\mathrm{Ar}$ & Bladon (1988), Pieters et al. (1990) \\
\hline Warjori Gt & Biotite granite; medium-grained & Intrudes Kemum Fm & $295-294$ & $2^{\mathrm{a}}$ & $\mathrm{K}-\mathrm{Ar}$ & Bladon (1988), Pieters et al. (1990) \\
\hline Melaiurna Gt ${ }^{\mathrm{d}}$ & $\begin{array}{l}\text { Pink porphyritic granites cut by dacite dykes; phenocrysts of } \\
\text { quartz, plagioclase, K-feldspar, and biotite in a groundmass of } \\
\text { quartz and feldspar. }\end{array}$ & $\begin{array}{l}\text { Intrudes Kemum Fm, but is not } \\
\text { metamorphosed; unconformably } \\
\text { overlain by Aifam Gp }\end{array}$ & $328-324$ & $2^{\mathrm{a}}$ & $\mathrm{K}-\mathrm{Ar}$ & $\begin{array}{l}\text { Amri et al. (1990), Bladon (1988), } \\
\text { Visser and Hermes (1962) }\end{array}$ \\
\hline
\end{tabular}

Abbreviations: Gdt: granodiorite, Gt: granite, N: number of samples dated

a Description or age obtained from alluvial river detritus samples, no in-situ sample available

${ }^{\mathrm{b}}$ No information available regarding sample type or location

c Four of the five samples of the Wariki Gdt are alluvial river detritus samples

d Previous name; we renamed the units 'Anggi Intrusive Complex' and 'Melaiurna Rhyolite' 
Supplementary Data File 1
Click here to download Background dataset for online publication only: SuppDataFile1.pdf

do dow

df

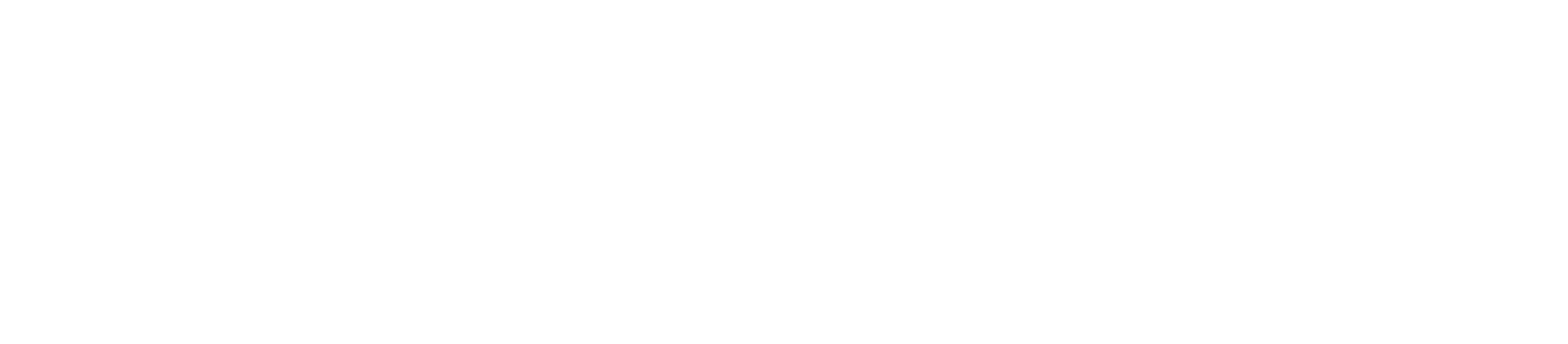

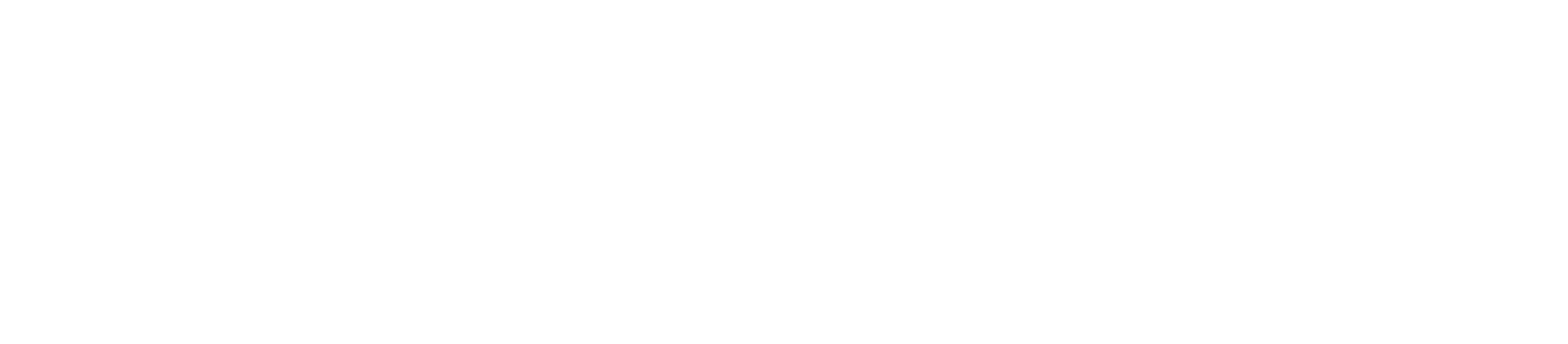

(1)

(1)

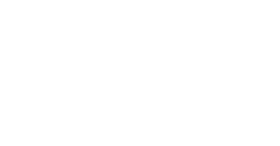

.

.

. 
Click here to download Background dataset for online publication only: SuppDataFile2.pdf

Supplementary Data File 2
Click here to download Ba

Click here to download Background dataset for online publication only: SuppDataFile2.pdf 
Supplementary Data File 3
Click here to download Background dataset for online publication only: SuppDataFile3.pdf Supplementary Data File 3
Click here to download Background dataset for online publication only: SuppDataFile3.pdf

\section{df}

(1)

(1)

(1)

(n)

(1) (1)

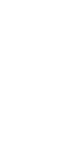
publication only: Suppoataries.pdf 

Supplementary Data File 4

Click here to download Background dataset for online publication only: SuppDataFile4.pdf

che here to download Background dataset for online publication only: Supp ataFiles.pdf

(n)

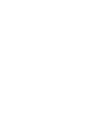

$\sqrt{10}$

$\sqrt{3}$

(1)

(1)

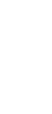
.

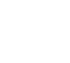

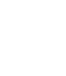

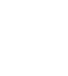

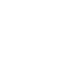
更

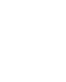

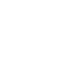

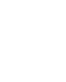

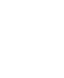

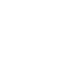
更

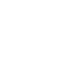

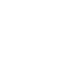


Supplementary Data File 5
Click here to download Background dataset for online publication only: SuppDataFile5.pdf

(a)

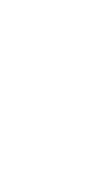

$\sqrt{10}$

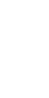

(1)

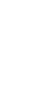

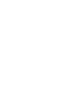

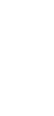

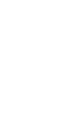
. (1)

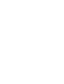

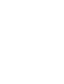
(1)

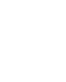

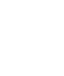

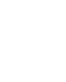

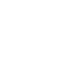

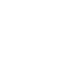

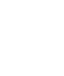
(1) . . . 
Supplementary Data File 6
Click here to download Background dataset for online publication only: SuppDataFile6.pdf

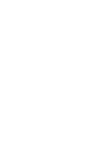

(

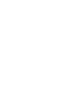

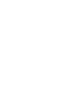

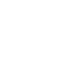

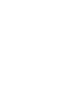

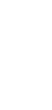

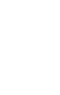
. .

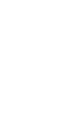
更

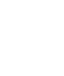
更

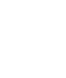

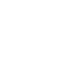

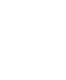

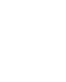

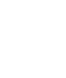

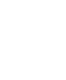

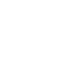

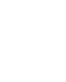

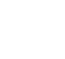


Click here to download Background dataset for online publication only: SuppDataFile7.pdf (1)

for

(1)

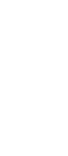
(1) (1) (1) (1) . . . . . . . . 
Click here to download Background dataset for online publication only: SuppDataFile8.xIsx Supplementary Data File 8
Click here to download Bac

Click here to download Background dataset for online publication only: SuppDataFile8.xlsx 
Supplementary Data File 9
Click here to download Background dataset for online publication only: SuppDataFile9.xIsx

Supplementary Data File 9
Click here to download Background dataset for online publication only: SuppDataFile9.xIsx 
Supplementary Data File 10
Click here to download Background dataset for online publication only: SuppDataFile10.pdf

Supplementary Data File 10
Click here to download Background dataset for online publication only: SuppDataFile10.pdf

\begin{abstract}
Ch here to download Background dataset for online publication only: SuppDataFile10.pdf
\end{abstract} (1) (a)

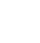

$\sqrt{20}$

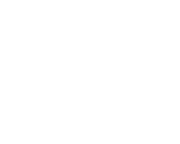

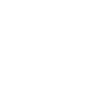

$\sqrt{3}$

$\sqrt{2}$ (1) (1) -

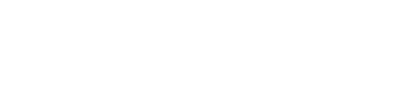
.

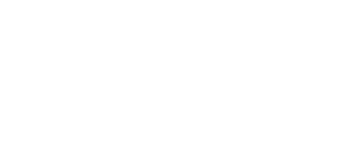

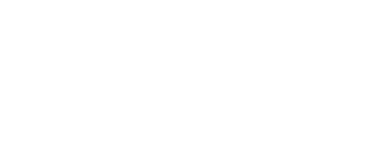

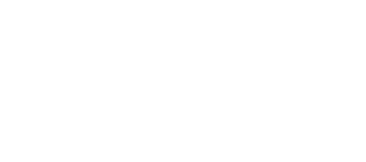
(1) (1) (1) (1) (1) (1) (1) (1) (1) (1) .

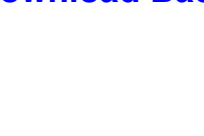

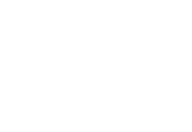
.

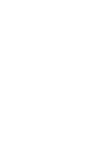

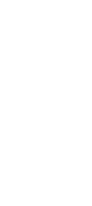
. 
Supplementary Data File 11
Click here to download Background dataset for online publication only: SuppDataFile11.pdf

Supplementary Data File 11
Click here to download Background dataset for online publication only: SuppDataFile11.pdf

che here to download Background dataset for online publication only: SuppataFile11.pdf

f

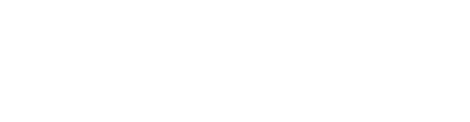

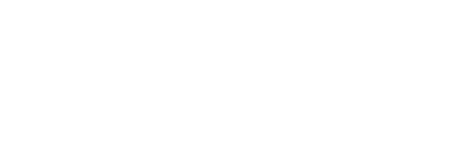

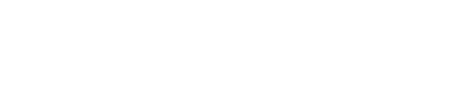

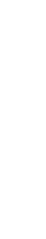

(1)

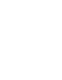

(1)

(1)

(1)

(1)

(1)

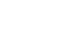

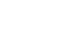

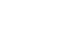

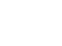

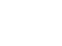

.

.

.

.

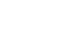

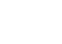

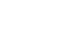

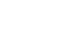

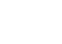

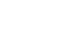

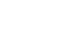

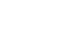

.

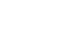


